Maurice A. Deane School of Law at Hofstra University Scholarly Commons at Hofstra Law

Hofstra Law Faculty Scholarship

2015

\title{
Trotting Out the White Horse: How the S.E.C. Can Handle Bitcoin's Threat to American Investors
}

J. Scott Colesanti

Maurice A. Deane School of Law at Hofstra University

Follow this and additional works at: https://scholarlycommons.law.hofstra.edu/faculty_scholarship

\section{Recommended Citation}

J. Scott Colesanti, Trotting Out the White Horse: How the S.E.C. Can Handle Bitcoin's Threat to American Investors, 65 Syracuse L. Rev. 1 (2015)

Available at: https://scholarlycommons.law.hofstra.edu/faculty_scholarship/677

This Article is brought to you for free and open access by Scholarly Commons at Hofstra Law. It has been accepted for inclusion in Hofstra Law Faculty Scholarship by an authorized administrator of Scholarly Commons at Hofstra Law. For more information, please contact lawcls@hofstra.edu. 


\title{
TROTTING OUT THE WHITE HORSE: HOW THE S.E.C. CAN HANDLE BITCOIN'S THREAT TO AMERICAN INVESTORS
}

\author{
J. Scott Colesanti, LL.M. ${ }^{\dagger}$
}

\author{
CONTENTS
}

INTRODUCTION: TROUBLE IN THE KINGDOM ........................................... 2

A. Bitcoin: Multiple Sources and Uses ...................................... 5

B. Obstacles to SEC Jurisdiction ................................................ 6

I. BitCoIn MECHANICS: PURGATORY IN THE DETAILS........................ 9

A. The New Currency? .............................................................. 9

B. The Investment Potential ..................................................... 12

C. The Language of Bitcoin Exchange Sites .............................. 14

D. Where the SEC Has/Has Not Addressed Bitcoin................... 16

II. EXISTING REgUlaTION OF "EXCHANGES"-ALlOWING

NO RAIDS ON THE CASTLE.......................................................... 18

A. What is an "exchange"? ..................................................... 18

B. Regulation ATS -An Accommodation with Strings Attached ............................................................................... 22

C. Application of "Exchange" Law to Bitcoin Exchange Sites ..................................................................... 25

III. ARMING THE WHITE KNIGHT ......................................................... 27

A. What is a "Security"?-The Howey Case and Its Progeny ................................................................................ 27

B. State of the Law on Howey Elements ................................... 30

1. "An investment of money. . ".......................................... 30

2. “... in a common enterprise. . .".................................... 32

3. " ... with the expectation of profits ...."........................ 34

4. "... derived solely from the efforts of others ...".......... 35

C. Raising the Drawbridge: Limitations on the Expansive Definition ........................................................... 36

D. Application of the Howey Test to Bitcoin Exchange Sites.... 38

1. Under a Strict Howey Analysis ...................................... 39

2. Under a Risk of Loss Analysis ..................................... 40

$\dagger$ J. Scott Colesanti is a Professor of Legal Writing at the Hofstra University Maurice A. Deane School of Law, where he has taught Securities Regulation every year since 2002. Professor Colesanti, a former industry regulator and arbitrator for ten years each, has had numerous articles published on securities fraud. He has lectured domestically and abroad on the financial crisis, its primary causes, and its inspired remedies. Professor Colesanti wishes to thank Craig Marinaro, Hofstra Law Class of 2016, for his assistance with the research for this article. 
3. As a Response to These Troubled Times ...................... 43

E. Counter-Analyses ................................................................ 45

IV. CONCLUSION: WEAPONS WITHIN REACH .................................... 47

A. On the SEC's Legitimacy ..................................................... 49

B. On the Practical Need for Uniformity ................................. 50

C. On the Public's Perception of the Crusade ........................... 51

\section{INTRODUCTION: TROUBLE IN THE KNGDOM}

Approximately five years ago, just as the Bull Market returned, a bold e-currency named Bitcoin emerged in cyberspace. ${ }^{1}$ Attending its launch was the promise that online vendors and anonymous consumers could transact commerce without the restrictions of nations or institutions. ${ }^{2}$ Indeed, the innovation was initially targeted for customers nobly resisting often inscrutable bank and other intermediary fees. ${ }^{3}$ But such attribution proved little more than reductive logic, as the cryptocurrency ${ }^{4}$ soon paved a redolent playground for those engaging in

1. For a brief, objective history of the phenomena, see generally CRAIG K. ELWELL ET al., CONG. Research SerV., R43339, U.S. CRS ANALyzes Virtual CuRRenCy's Legal AND REGULATORY IsSUES (2014) [hereinafter CRS Summary]. For a more pointed view, see EOG Bitcoins and Sports Wagering - Birth of Bitcoins, EYE ON GAMING (Mar. 4, 2014), www.eog.com/eog-bitcoins-sports-wagering-birth-bitcoins/.

2. See generally Frank J. Diekmann, Diekmann: The Risk In Currency \& The Currency of Risk, CREDIT UNON JOURNAL (Apr. 25, 2014, 10:02AM), http://www.cujournal.com/news/diekmann-the-risk-in-the-currency-and-the-currency-ofrisk-1022509-1.html; Freddy Gray, Welcome to crypto-currency land, THE SPECTATOR (Apr. 26, 2014), http://www.spectator.co.uk/columnists/the-speculator/9189611/are-cryptocurrencies-the-future-of-money/ (identifying the largest holders of virtual currencies only as "???").

3. See, e.g., Press Release, Dep't of Treasury, Remarks From Under Sec'y of Terrorism and Fin. Intelligence David S. Cohen on 'Addressing the Illicit Fin. Risks of Virtual Currency,' (Mar. 18, 2014), available at http://www.treasury.gov/press-center/pressreleases/Pages/j1236.aspx (noting the "intense enthusiasm" for virtual currencies because of the belief "shared by consumers, businesses, and investors alike" that such alternatives "lower transaction costs, increase access to capital, and bring financial services to many unbanked individuals").

4. Cryptocurrency

Definition,

INVESTOPEDIA, http://www.investopedia.com/terms/c/cryptocurrency.asp (last visited Mar. 18, 2014). "Cryptocurrency" is most aptly described by what it is not: a currency tied to a nation, manifested in paper form. A working definition calls it a "digital or virtual currency that uses cryptography for security." Id. See also SEC v. Shavers, No. 4:13CV00416, 2013 WL 3810441, I 2 (E.D. Tex. July 23, 2013), in which the SEC defines Bitcoin as "a virtual currency that may be traded on online exchanges for conventional currencies, including the U.S. dollar, or used to purchase goods and services online. [Bitcoin] has no single administrator, or central authority or repository." 
Ponzi schemes and shocking criminal activities. ${ }^{5}$ The investment allure has garnered less regulatory attention, despite a vault in single Bitcoin price from thirteen dollars in January 2013 to over $\$ 1,100$ in December of the same year. ${ }^{6}$ Not surprisingly, notorious entrepreneurs resurfaced, spearheading companies poised to capitalize on the Bitcoin craze. ${ }^{7}$

Consequentially, as regulators were forced to select the most alarming examples of cyber-fraud to cabin this new threat, ${ }^{8}$ criminal prosecution has often been the most ready fit. ${ }^{9}$ Civil agencies have adopted less certain - and diametrically opposed-stances (i.e., the Internal Revenue Service ${ }^{10}$ and the Department of Treasury ${ }^{11}$ ).

5. Takashi Mochizuki, Japanese Regulators Take Closer Look at Bitcoin, THE WALL STREET JOURNAL (May 5, 2014, 8:00 AM), available at http://online.wsj.com/news/articles/SB10001424052702304071004579406331583977114; Mridhula Raghavan, U.S. authorities probe bitcoin exchanges over illegal transactions: WSJ, REUTERS (May 19, 2014, 9:04 PM), http://www.reuters.com/article/2014/05/20/ususa-crime-bitcoin-idUSBREA4J01P20140520 (disclosing subpoenas issued to the leading Bitcoin exchange seeking information on "ties between the exchanges and the online drug market Silk Road"); Peter J. Henning, For Bitcoin, Square Peg Meets Round Hole Under the Law, N.Y. TIMES (Dec. 9, 2013, 11:43 AM), http://dealbook.nytimes.com/2013/12/09/for-bitcoin-square-peg-meets-round-hole-underthe-law/ ("The government seized nearly 175,000 Bitcoins, so clearly virtual currency can be used to buy drugs as if it were cash on a street corner."); Last Week Tonight With John Oliver (HBO comedy series May 11, 2014) (viewing the phenomena as much more intertwined with fraud, calling Bitcoin the currency of "heroin dealers and pornographers").

6. Stephen Bell, Blog, "Bitcoin Entrepreneur Readies Australia Listing for New $\begin{array}{lllllll}\text { Venture,"THE WALL STREET JOURNAL (Mar. 11, } 2014 & \text { 8:09 PM) }\end{array}$ http://blogs.wsj.com/moneybeat/2014/03/11/bitcoin-entrepreneur-readies-australia-listingfor-new-venture/.

7. See Brad Stone, Halsey Minor Returns, Bearing Bitcoins, BLOOMBERG BUSINESSWEEK (May 15, 2014), http://www.businessweek.com/articles/2014-05-15/halseyminor-returns-bearing-bitcoins-via-bitreserve (describing the plans of Bitreserve, a Cayman Islands company that has filed for an IPO, and its CEO, a noted "Internet entrepreneur" whose has seen his $\$ 400$ million fortune subject to "calamity").

8. See generally Kim Zetter, FBI Fears Bitcoin's Popularity with Criminals, WIRED (May 9, 2012, 10:51PM), http://www.wired.com/2012/05/fbi-fears-bitcoin/; see also Cyrus Sanati, Bitcoin looks primed for money laundering, FORTUNE (Dec. 18, 2012, 7:49 PM), $\mathrm{http} / / /$ fortune.com/2012/12/18/bitcoin-looks-primed-for-money-laundering/.

9. How Bitcoin Works, Forbes ONLINE (Aug. 1, 2013, 12:25 PM), http://www.forbes.com/sites/investopedia/2013/08/01/how-bitcoin-works/. The most colorful Bitcoin prosecution to date involves the case against the Bitcoin pioneer who called himself "Dread Pirate Roberts." See United States v. Ross William Ulbricht, 2014 U.S. Dist. LEXIS 93093 (S.D.N.Y. July 9, 2014) (denying defendant's Motion to Dismiss in its entirety). Even free market publications have noted as a "disadvantage" to Bitcoin the specific evils it opportunes: "The relative anonymity of Bitcoin may encourage its use for illegal and illicit activities such as tax evasion, weapons procurement, gambling and circumvention of currency controls." How Bitcoin Works.

10. See Michael Cooney, IRS: Bitcoin is property not money; IRS says virtual currency has no legal tender status in any jurisdiction, NETWORK WORLD (Mar. 25, 2014, 
Securities regulators have been quick to caution-the North American Securities Administrators Association ("NASAA") lists digital currencies as one of two new threats to investors on its eponymous annual list. ${ }^{13}$ But, in the main, the newness of these e-currencies has proven a challenge for tangible regulatory response by even sufficiently alarmed watchdogs. ${ }^{14}$ And the U.S. Securities and Exchange

5:21 PM), http://www.networkworld.com/article/2175530/security/irs-bitcoin-is-propertynot-money.html. The IRS has, for now, sidestepped the controversy by deeming Bitcoin gains and losses as "property transactions." Id.

11. See Application of FinCEN's Regulations to Persons Administering, Exchanging or Using Virtual Currencies, DePARTMENT OF THE TREasury FinanCIAL CRIMES $\begin{array}{llll}\text { ENFORCEMENT NETWORK (Mar. } & 18, & \text { 2013), }\end{array}$ http://fincen.gov/statutes_regs/guidance/html/FIN-2013-G001.html. FinCEN's guidance declares that parties "mining" Bitcoins for others or exchanging Bitcoins for cash must comply with the registration requirements of the money laundering regulations promulgated under the Bank Secrecy Act. To date, FinCEN has stopped short of subjecting Bitcoin transactions exceeding a monetary threshold in value to reporting requirements. Id.See alsoPress Release, supra note 3 for the proposition that "we will need to consider whether to apply 'cash-like' reporting requirements to the virtual currency space", and Jenna Greene, Playing Hot Potato: Regulators may be interested in overseeing bitcoin, but it's not clear which can or will, CORPORATE COUNSEL (June 1, 2014), http://www.corpcounsel.com/id=1202655860491/Playing-Hot-Potato; Kashmir Hill, Every Important Person in Bitcoin Just Got Subpoenaed by New York's Financial Regulator, Forbes (Aug. 12, 2013, $1: 43 \quad$ PM), http://www.forbes.com/sites/kashmirhill/2013/08/12/every-important-person-in-bitcoin-justgot-subpoenaed-by-new-yorks-financial-regulator/.

12. See Regulatory \& Legal Activity, N. AM. SEC. ADM'RS Assoc. (last visited August $3,2014)$, www.nasaa.org/regulatory-activity/. NASAA is an organization that predates the federalization of securities laws, and serves as the voice of state securities regulators. Id. The organization issues many investor alerts and actively testifies before Congress, but it has no rulemaking or enforcement apparatus and must rely on its members to bring disciplinary action. $I d$.

13. The full warning on NASAA's website is as pointed as it is colorful:

Virtual reality may exist only in science fiction, but consumers now are able topurchase goods and services with virtual money such as Bitcoin, PP Coin and other digital currencies. Unlike traditional coinage, these alternatives typically are not backed by tangible assets, are not issued by a governmental authority andare subject to little or no regulation. The value of Bitcoins and other digital currencies is highly volatile and the concept behind the currency is difficult to understand even for sophisticated financial experts given the complicated mathematical algorithms that determine when new blocks of coins will be released. This environment has provided fertile ground for scam artists to capitalize on the increasing popularity and acceptance of digital currencies. Investors should be aware that investments that incorporate abstract money systems present very real risks, including the possibility of virtual reality leaving an investor virtually broke.

Top Investor Threats, N. AM. SEC. ADM'RS Assoc. (last visited August 3, 2014), http://www.nasaa.org/3752/top-investor-threats/.

14. See Henning, supra note 5 ("Currency, even the virtual types, is usually not understood to be a security or commodity subject to regulation by the Securities and 
Commission ("SEC" or "Commission") has stepped slowly in its inevitable march towards regulation, no doubt in part because of the wide variety of Bitcoin arrangements.

\section{A. Bitcoin: Multiple Sources and Uses}

In its present state, the Bitcoin market is populated by three categories of issuers. "Mining" websites assist Bitcoin purchasers with efforts to create new Bitcoins. ${ }^{16}$ It has been aptly noted that idyllic use of the free source computer code is well beyond the capability of individuals armed only with a mobile device, laptop, or personal computer; ${ }^{17}$ regardless, any attempt by the SEC to universally apply a reading of "security" to all Bitcoins would be felled by the purchaser's significant efforts in mining. ${ }^{18}$

A second categorical source of Bitcoins is the secondary market (i.e., merchants and Miners re-selling Bitcoins to third parties). ${ }^{19}$ Such market is nearly unidentifiable, and such actions appear more true to Bitcoin's original purpose (i.e., as currency) rather than speculative investment. $^{20}$

But a third, vast market for Bitcoins is populated by selfproclaimed "exchanges," an appreciable number of which misrepresent exchange status or disappear under questionable circumstances. ${ }^{21}$ Offering a quick entrance to the highly volatile Bitcoin market, these highly publicized cyber-entities pose a real and potentially catastrophic threat to the American investing public. ${ }^{22}$ Further, these entities are openly availing themselves of the goodwill attending policed

Exchange Commission or the Commodity Futures Trading Commission.").

15. CRS Summary, supra note 1 , at 5.

16. Id.

17. Id. (declaring the "probability of an individual discovering Bitcoins through mining" to be "very small").

18. See infra Part III (discussing the application of securities law to various Bitcoin websites).

19. CRS Summary, supra note 1 , at 5 .

20. See Complaint I 2, SEC v. Shavers, No. 4:13CV00416, 2013 WL 3810441 (E.D. Tex. July 23, 2013) (alleging only that Bitcoin satisfies the prerequisite of "money" in determining the presence of an investment).

21. See Crayton Harrison \& Jesse Hamilton, Bitcoin Exchange Tradehill Pauses for Regulatory Reasons, BLOOMBERG (Aug. 30, 2013) (noting the exchange's halt for "unspecified banking and regulatory reasons"); see also Vitalik Buterin, Bitfloor Hacked, $\$ 250,000$ Missing, BITCOIN MAGAZINE (Sept. 4, 2012), $\mathrm{http} / /$ bitcoinmagazine.com/2139/bitflooor-hacked-250000-missing/. Indeed, the stories of disasters harming Bitcoin exchanges nearly defies tally.

22. CRS Summary, supra note 1, at 7 . 
exchanges. $^{23}$

Accordingly, this Article posits that the SEC can and must address these common and commonly misconstrued conduits. ${ }^{24}$ To state it bluntly, in the five years of its formal existence, Bitcoin's use as an alternative to "PayPal" or Western Union has likely been overridden by its utility as an aggressive mutual fund. Loosely-based tales of an individual Bitcoin's worth have prospered, even in the face of a spectacular crash in late $2013 .^{25}$ SEC regulation is not as farfetched as once feared. Once Bitcoin "exchanges"26 are sheared of their cover, they too often more closely resemble old-fashioned offers for quick gains by promoters ("Promoters") for speculative investments to unsophisticated investors ("Investors").

To wit, to enable effective SEC regulation, all Bitcoin Exchange Sites offering Bitcoins as a speculative investment to buyers expending only cash need to be considered Promoters; likewise, all purchasers of Bitcoin under circumstances clearly evidencing said passive investment need to be considered Investors. As a Promoter of an offering of securities, such Sites need to register with the Commission, even if prompted by SEC enforcement action. ${ }^{27}$

\section{B. Obstacles to SEC Jurisdiction}

To be sure, the grounds for such SEC regulation are vulnerable. ${ }^{28}$ First, in determining the presence of a security, the Bitcoin purchase arrangement-albeit varied-is still largely unprecedented. Paperwork is nearly non-existent, eliminating comfortable comparisons to a statutory "investment contract." 29 Apart from the difficulty in applying

23. See Securities Exchange Act of 1934, 15 U.S.C. $\$ 78 \mathrm{c}(\mathrm{a})(1)$; see also Exchange Act Release No. 55631, 2006 WL 6324802 (Apr. 12, 2006) (detailing the strict requirements attending exchange registration).

24. For a broader, more generalized call for regulatory action, see Ruoke Yang, When Is Bitcoin A Security Under U.S. Securities Laws?, 18 J. TECH L. \& POL'Y 99, 114-15 (2013) (concluding that Bitcoin-however generated or used-satisfies all of the Howey Test factors described later herein).

25. See SEC v. Shavers, No. 4:13CV00416, 2013 WL 3810441, at 12 (E.D. Tex. July 23 , 2013) (stating the online "Bitcoin Forum" provides regular valuations, as well as "[Bitcoin]-denominated investment opportunities"); see also CRS Summary, supra note 1, at 5; see generally Kevin Maney, The Other Side of Bitcoin, NEwswEEK (March 28, 2014, 1:58 PM), http://www.newsweek.com/2014/03/28/other-side-bitcoin-248009.html.

26. For purposes of this Article, Internet entities offering to buy, sell, trade, or house Bitcoins will be referred to "Bitcoins Exchange Sites," or simply "Sites."

27. See supra note 25.

28. See Henning, supra note 5.

29. SEC v. Howey, 328 U.S. 293, 298 (1946) (interpreting the meaning of "investment contract" under the Securities Act of 1933). 
that statutory definition to a Bitcoin transaction, parties mining Bitcoins do not make an investment in a "bond," or "note." ${ }^{30}$ Moreover, Bitcoin-when defined-is most often labeled as a form of currency, which, by definition, normally evades application of the securities laws. ${ }^{31}$ As such, the Bitcoin arrangement does not readily satisfy even the generous definitions afforded by the Securities Act of $1933^{32}$ nor the Securities Exchange Act of $1934 .^{33}$

Second, the myriad pressures in 2014 on SEC attention make Bitcoin a likely back-burner issue. The vexing issues of Dodd-Frank Act rulemaking, increased criminalization of the fraud provisions of the securities laws, and tangles with activist courts ${ }^{34}$ all augur poorly for expansion of Commission jurisdiction in a targeted, highly

30. See Reves v. Ernst \& Young, 494 U.S. 56, 67 (1990) (holding that the notion that "note[s]" are presumed securities-subject to myriad factors evidencing commercial paper-this "family resemblance test"); see also SEC v. Thompson, 732 F.3d 1151, 1170 (10th Cir. 2013) (finding unsecured promissory notes to be securities under federal law. The "family resemblance test" utilized by the Reves Court-as a means of distinguishing commercial paper from securities-is still followed.).

31. See Henning, supra note 5 (stating that, to date, the formal positions espoused by federal securities regulators define Bitcoin as a currency); see also Investor Alert: Ponzi Schemes Using Virtual Currencies, SEC Office of Investor Educ. and Advocacy (July 2013), www.sec.gov/investor/alerts/ia_virtualcurrencies.pdf. ("Virtual currencies, such as Bitcoin, have recently become popular and are intended to serve as a type of money."); Investors Protect Yourself, Bitcoin: More than a Bit Risky, FINRA (Updated May 7, 2014), www. finra.org/Investors/ProtectYourself/InvestorAlerts/FraudsAndScams/P456458. In terms of policy established via litigation, the SEC has brought a handful of cases targeting companies using Bitcoin's appeal to gain investors in speculative enterprises. Id.; see also SEC v. Shavers, 2013 WL 4028182, *1 (E.D. Tex. Aug. 2013); Newcomb, infra note 95.

32. Securities Act of 1933 ("1933 Act"), 15 U.S.C. $\$ \S 77 \mathrm{a}-77 \mathrm{bbbb}(2012)$; see also Nat'l Assoc. of Sec. Dealers, Exchange Act Release No. 37538, 1996 WL 447193 (Aug. 8, 1996); N.Y. Stock Exch. Inc., Exchange Act Release No. 41574, 1999 WL 430863 (June 29, 1999); N.Y. Stock Exch. Inc., Exchange Act Release No. 51524, 2005 WL 840452 (Apr. 12, 2005); N.Y. Stock Exch. LLC, Exchange Act Release No. 67857, 2012 WL 4044880 (Sept. 14, 2012); N.Y. Stock Exch. LLC, Exchange Act Release No. 72065, 2014 WL 1712113 (May 1, 2014).

33. Securities and Exchange Act of 1934 ("1934 Act"), 15 U.S.C. $§ \S 78 a-77111$ (2012). The 1933 Act and 1934 Act shall be collectively referred to in this Article as "the Securities Acts."'In addition, see Great Rivers Coop. v, Farmlands Indus., 198 F.3d 685, 699 (8th Cir. 1999), which found no security in farm cooperative notes, notwithstanding the issuer's registration with both the SEC and State authorities. It thus bears noting that even registration with the SEC does not always establish the presence of a "security" for purposes of applying the Securities Acts.

34. See, e.g., Mark Hamblett, Panel Upsets Rakoff Ruling in Citigroup/SEC Settlement, N.Y.L.J. (June 5, 2014), available at http://www.litigationdaily.com/id=1202658021852/Panel-Upsets-Rakoff-Ruling-inCitigroupSEC-Settlement (discussing the tussle between the Commission and U.S. District Judge Jed Rakoff over the standard of review attending hearings on SEC settlements). 
technological area. Moreover, the question of whether to regulate or not regulate has, perhaps predictably, taken foot on Capitol Hill. ${ }^{35}$ Not surprisingly, sporadic SEC enforcement action to date has trumpeted the word "Bitcoin," 36 but has done little to assuage the fears that swindled investors will someday demand remedy.

However, the public's thirst for faddish investments in Bitcoins is undeniable ${ }^{37}$-and strikingly familiar of the Tulip Bulb Craze of the seventeenth century. ${ }^{38}$ The Internet is presently besieged by scores of Bitcoin Exchange Sites. State regulators are arriving at varying means of shielding their citizens. ${ }^{39}$ While a handful of Bitcoin-related investment companies have registered with the Commission, ${ }^{40}$ the cryptocurrency as an investment unto itself remains wholly distant from the government's radar.

The unchecked and growing use of Bitcoin as an investment shouts for regulation. In the past forty years, the Commission has chilled quixotic offers by expanding its reach to, among other areas, real estate deals, purely synthetic investments, "death bonds," and internetgaming. ${ }^{41}$ Likewise, the storied federal agency needs to immediately

\footnotetext{
35. Rebecca Robbins, Bitcoin is barely regulated-and these congressmen want to keep it that way, WASHINGTON POST (July 30, 2014), http://www.washingtonpost.com/blogs/the-switch/wp/2014/07/30/bitcoin-is-barelyregulated-and-these-congressmen-want-to-keep-it-that-way/ (picturing industry representatives fielding questions in the foyer of the Rayburn Office Building during "Bitcoin Demo Day").
}

36. See Nat'l Assoc. of Sec. Dealers, Exchange Act Release No. 37538, 1996 WL 447193 (Aug. 8, 1996); N.Y. Stock Exch. Inc., Exchange Act Release No. 41574, 1999 WL 430863 (June 29, 1999); N.Y. Stock Exch. Inc., Exchange Act Release No. 51524, 2005 WL 840452 (Apr. 12, 2005); N.Y. Stock Exch. LLC, Exchange Act Release No. 67857, 2012 WL 4044880 (Sept. 14, 2012); N.Y. Stock Exch. LLC, Exchange Act Release No. 72065, 2014 WL 171213 (May 1, 2014).

37. See, e.g., A.H. SMithers, EVERYthing you NEEd to KNOW ABOUT BUYING, SELLING AND INVESTING IN BITCOIN (2013); RICHARD FORBES, BITCOIN GUIDE FOR Beginners: The Essential Beginner's Guide to Buying, Selling, And Investing in Bitcoin (2014); Devon WilcoX, Bitcon BeginNeR's Guide: Everything You NeEd To Know To Become Rich With Bitcoins (2014); Sam Patterson, Bitcon BeginNer: A Step By Step Guide To Buying, Selling AND INVESTing IN Bitcoins (2013).

38. See J. Scott Colesanti, "Circuit Breakers" and the Mission of Stock Market Stability, 15 NExus 43, 43-44 (2009/2010) (describing the storied European Tulip Bulb craze of the seventeenth Century).

39. See Weinberger, infra note 330; Jackson, infra note 331.

40. See Bitreserve Ltd. (Form D) (Feb. 26, 2014), available athttp://formd.findthebest.com/1/153913/Bitreserve-Ltd (disclosing revenues of $\$ 1.65$ million in three months and a minimum investment size of $\$ 50,000)$; see also Winklevoss Bitcoin Trust, Registration Statement (Form S-1) (July 1, 2013), available at http://www.sec.gov/Archives/edgar/data/1579346/000119312513279830/d562329ds 1.htm .

41. See infra Part III.E. 
regulate self-proclaimed Bitcoin "exchanges" where such entities are advertising Bitcoin as an investment and concurrently offering to assist its purchasers desirous of passive profits. ${ }^{42}$

Accordingly, this Article explores the application of the definitional and registration sections of the securities laws to Bitcoin arrangements representing secondary sales of Bitcoin (i.e., from Sites to customers, for cash) under circumstances evidencing speculative intent. Concomitantly, the Article urges the SEC to solidify and prioritize its heretofore random policing of such poorly understood investments.

Part I of this Article provides detailed background on the Bitcoin phenomena, a notion at once curiously ubiquitous and dangerously nascent in development. Part II describes the state of the statutory definition of "stock exchange" and concludes that Bitcoin Exchange Sites, for many reasons, are a poor fit. Part III similarly addresses the state of the statutory definition of "security." Part III also suggests SEC registration as a security as the solution to the particularized investment problem posed by Bitcoin, a device laudably conceived which has succumbed to the pragmatic lure of yet another "get rich quick scheme" for U.S. investors. Further, based upon a review of numerous websites designed to buy, sell, or hold Bitcoins, Part III offers a three-part disjunctive analysis by which regulators could discern whether a Bitcoin "exchange" is acting foremost to promote Bitcoin as an investment.

Finally, Part IV highlights the practical efforts by State regulators to cabin this investment threat while reminding of the open-ended mission of the preeminent agency charged with protecting American investors of every ilk.

\section{BitCoin Mechanics: PuRgatory IN THE Details}

\section{A. The New Currency?}

The details of Bitcoin are simplistic in theory, yet surreal in effect. On one level, an anonymous party uses an "open source" (i.e., free and public) ${ }^{43}$ computer code to generate a personal address while establishing the capability of calculating pending Bitcoin transactions (a mathematical contest/computational process known as "Mining"). ${ }^{44}$. This process creates personal Bitcoins in modest amounts (presently set at twenty-five). ${ }^{45}$ These new coins are held by the successful "Miner" in

42. See, e.g., CRS Summary, supra note 1, at 4-5.

43. Id. at 5 .

44. Id.

45. How Bitcoin Works, supra note 9. 
virtual "wallets" and disbursed to pay online debts for goods and services. ${ }^{46}$ There is no central overseeing authority. ${ }^{47}$ Once "Mined," the coins reside in cyberspace, retrievable only by the respective wallet's creator, who is identified by an alias. ${ }^{48}$ Wallets (utilized by both Miners and others) can be kept on a personal computer (also known as a "standalone" wallet) or may be maintained by various websites offering to buy, sell, convert, and/or store Bitcoins. ${ }^{49}$

On a larger scale, a clear picture of the notorious monetary alternative is absolutely ephemeral-and terrifying. An individual (or individuals) cyber-named "Satoshi Nakamoto" started the entire craze with a highly technical 2008 research paper that portended a commercial e-payment system without middlemen. ${ }^{50}$ "Satoshi Nakamoto" subsequently left the network; earlier this year, a California engineer with the name "Dorian Satoshi Nakamoto" disputed an article in Newsweek identifying him as Bitcoin's legendary founder. ${ }^{51}$

More importantly, even for those comprehending underlying "encryption techniques," there are seemingly random individual choices ranging from residence for the digital wallet (e.g., a website or a mobile device) to the choice of a sole wallet or unlimited wallets. ${ }^{52}$ Also, there are arbitrary network decisions being made by unknown operators. For example, only twenty-one million Bitcoins shall ultimately be generated, less than $50 \%$ away from the present volume. ${ }^{53}$

The points of contact of Bitcoins may vary with the jurisdiction's degree of safeguarding. In some locales, Bitcoins are virtually dispensed

46. CRS Summary, supra note 1, at 4-5.

47. Id; see also Monami Yui \& Takahiko Hyuga, Japan Says Bitcoin Not Currency Amid Calls for Regulation, BlOOMBERG, 2 (Mar. 7, 2014), http://www.bloomberg.com/news/2014-03-07/japan-says-bitcoin-is-not-a-currency-amidcall-for-regulation.html (noting that Bitcoin exchanges had been subjects to hacking thefts and that Bitcoin "has no central issuing authority").

48. See generally Diekmann, supra note 2. While physical Bitcoins exist, these are novelty items.

49. Princess Clark-Wendel, How Safe is Your Bitcoin Wallet From a Cyber-Attack?, FORBES ONLINE (July 28, 2014, 11:00 AM), http://www.forbes.com/sites/sungardas/2014/07/28/how-safe-is-your-bitcoin-wallet-from-a cyber-attack/.

50. See Satoshi Nakamoto, Bitcoin: A Peer-to-Peer Electronic Cash System, available at http://bitcoin.org/bitcoin.pdf.

51. Roger $\mathrm{Yu}$, Nakamoto hires lawyer, 'unconditionally' denies Bitcoin role, USA

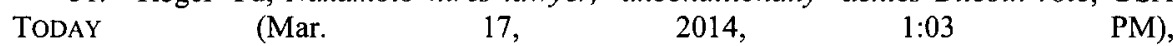
http://www.usatoday.com/story/money/business/2014/03/17/nakamoto-hireslawyer/6520011/.

52. See Clark-Wendel, supra note 49.

53. How Bitcoin Works, supra note 9. 
from "kiosks" and ATMs. ${ }^{54}$ More likely, the majority of Bitcoins are purchased online from a Bitcoin Exchange Site as an alternative to the computations required of the Mining process. ${ }^{55}$ Such "exchanges" have proven to be transient and dubious. ${ }^{56}$ Moreover, a great amount of braggadocio has surfaced. ${ }^{57}$ Even when maintaining standards and solvency, Bitcoin "exchanges" can confound observers with their dichotic transparency: while individual users remain unknown, all Bitcoin transactions (and pseudonyms attached to the corresponding encrypted addresses) are ultimately visible to anyone via a public site called "Blockchain"s8

Despite their points of origin, Bitcoin transactions are largely paperless, irreversible, uninsured, and relatively slow (a confirmation takes at least ten minutes). ${ }^{59}$ Of course, the most vexing variable is ultimate user-friendliness, for it is not yet certain how many websites can help one Mine coins, nor how many vendors and counterparties will ultimately accept the currency (although there have been some significant additions to the latter roster). ${ }^{60}$ Noteworthy is the

54. U.S. Gov't Accountability Office, GAO-14-496, Virtual Currencies 4 (May 29, 2014) [hereinafter GAO Report].

55. How Bitcoin Works, supra note 9.

56. See, e.g., In re Virtual Mining Corp. (The Missouri Complaint), 2014 Mo. Sec. LEXIS 12, 3 (2014) ("Due to regulatory concerns, several Bitcoin exchanges have ceased operations.").

57. See, e.g., What is Bitcoin?,Bitstamp, https://bitstamp.net/help/what-is-bitcoin? (last visited Aug. 9, 2014) ("BITCOIN IS BETTER THAN GOLD").

58. BLOCKCHAIN, https://blockchain.info (last visited Oct. 20, 2014); see also Gray, supra note 2.

59. How Bitcoin Works, supra note 9.

60. For example, in late July, the online research resource Wikipedia announced that it would accept donations in Bitcoin form. Sydney Ember, Wikipedia Begins Taking Donations in Bitcoin, N.Y. TIMES (July 30, 2014, 6:48 PM), http://dealbook.nytimes.com/2014/07/30/wikipedia-begins-taking-donations-in-bitcoin.

Earlier in the year, the U.S. Federal Election Commission agreed to accept Bitcoin political contributions under existing law defining "money or anything of value." Nick Corasaniti, Election Commission Votes to Allow Bitcoin Donations, N.Y. TIMES (May 8, 2014), http://www.nytimes.com/2014/05/09/us/politics/election-commission-votes-to-allow-

bitcoin-donations.html; Fed. Election Comm'n, Advisory Op., RE: Advisory Opinion Request of Conservative Action Fund PAC (No. 2013-15) (Aug. 15, 2013), available at http://saos.fec.gov/saos/searchao (search for AO Number 2013-15) (noting the elastic definitions of "contribution," "money," and "anything of value" within the Federal Election Campaign Act, 2 U.S.C. $\S 431(8)$ or attendant regulations, 11 C.F.R. § 100.52(a-d) (2012)). Likewise, Overstock.com and Dish Network both accept Bitcoin as payment for their products. Michael J. Casey, Dish Network to Accept Bitcoin Payments, Satellite TV Company Will Accept Virtual Currency Beginning in July, WALL STREET JouRNAL (May 29, 2014, 9:19 PM), http:/online.wsj.com/articles/dish-network-to-accept-bitcoin-payments1401363621; Kevin Maney, The Other Side of Bitcoin, NEwsweEK (March 28, 2014, $1: 58$ 
unfathomable proliferation of unrelated websites offering to facilitate its market and growth. ${ }^{61}$ Mishaps are well- documented ${ }^{62}$ Embarrassingly, the CEO of a Bitcoin exchange (and a leader on the Board that promotes Bitcoin's growth) was recently charged with money laundering, ${ }^{63}$ casting further and grave speculation about the e-currency's potential for legitimate use. ${ }^{64}$

\section{B. The Investment Potential}

Nonetheless, consumers/customers have eagerly progressed to investors. ${ }^{65}$ It is estimated that in excess of twelve million Bitcoins exist in cyberspace. ${ }^{66}$ Meanwhile, the popular press is flush with hardcover

PM), http://www.newsweek.com/2014/03/28/other-side-bitcoin-248009.html. It is estimated that approximately 20,000 merchants now accept Bitcoin, the incentive generally believed to be an avoidance of a credit card processing fee of $3 \%$. Not everyone is following this trend, however. See, e.g., James Ching, Hysteria Grips Bitcoin Market as Apple Removes Bitcoin Wallet App from Its Store, 30 E-COMMERCE LAW AND STRATEgY 1 (March 1, 2014), http://www.lawjournalnewsletters.com/issues/ljn_ecommerce/30_11/news/hysteria_grips_bi tcoin_market_as_apple_removes_bitcoin_wallet_app_from_its $159285-1 . \mathrm{html}$.

61. Id.; see also Complete List of Bitcoin Exchanges, 70+ Sites, Bourses, and Platforms From Around the World, PLANET BITCON, www.planetbtc.com/complete-list-ofbitcoin-exchanges (last visited Oct. 20, 2014) [hereinafter Complete List of Bitcoin Exchanges, 70+ Sites]. The site was apparently suspended in November of 2014.

62. See Bitcoin: More than a Bit Risky, infra note 163; Mark Thompson, Bitcoin market Mt. Gox files for bankruptcy, CNN Money (Feb. 28, 2014, 8:24 AM), http://money.cnn.com/2014/02/28/investing/mt-gox-bankruptcy; Greene, supra note 11; see also Monamiyui Yui \& Takahiko Hyuga, Japan Says Bitcoin Not Currency Amid Calls for Regulation, BLOOMBERG (Mar. 7, 2014, 12:13 AM), http://www.bloomberg.com/news/2014-03-07/japan-says-bitcoin-is-not-a-currency-amidcalls-for-regulation.html (noting the loss of 896 Bitcoins by an Alberta, Canada bank to hackers in March 2013, which forced the bank to close).

63. Donna L. Leger, Bitcoin pioneer facing federal charges quits foundation, USA TODAY (Jan. 28, 2014, 2:05 PM) (describing charges against Charlie Shrem, CEO of BitInstant and attendant scandal at the Bitcoin Foundation), http://www.usatoday.com/story/tech/2014/01/28/shrem-resigns-from-bitcoinfoundation/4961903/.

64. Cf. CRS Summary, supra note 1, at 11-12 (noting Bitcoin exchange failures in the United States, Australia, and Japan). But see Hugh Starr, Harvard Economics Professor Makes the Case For Bitcoin, THE CRYPTO CRIMSON (May 21, 2014), http://cryptocrimson.com/2014/05/harvard-economics-professor-makes-case-bitcoin (blessing Bitcoin as an alternative to the large amount of debt taken on by governments in recent years).

65. Kevin Maney, The Other Side of Bitcoin,NewsweEK (Mar. 19, 2014, 1:58 PM), http://www.newsweek.com/2014/03/28/other-side-bitcoin-248009.html ("As more people bought [B]itcoin, the value rose, which in turn drew in more investors.").

66. Jenna Greene, SEC Warns Investors About Bitcoin, LEGAL TIMES (May 7, 2014, 12:53 PM), http://www.nationallawjournal.com/legaltimes/id=1202654353187/SEC-WarnsInvestors-About-Bitcoin (quoting a public SEC Investor alert: "As a recent invention, [B]itcoin does not have an established track record of credibility and trust."). 
guides on making easy profit from this virtual treasury, ${ }^{67}$ and individual coins (even after a spectacular free market fall) have been recently valued as high as $\$ 600$ each. ${ }^{68}$ Bitcoin's widely disseminated price ranged from a high of $\$ 1100$ in December 2013 to a dramatic low of $\$ 400$ in April 2014 (a 63.6\% swing). ${ }^{69}$ Hedge funds and professional traders actively comment on the upside potential. ${ }^{70}$ Not surprisingly, putative exchanges conjuring images of traditional stock exchanges have emerged, often promising to swell wallets or convert their holdings to tangible profits. ${ }^{71}$ As a result, the enormity of the e-currency, the related mystical events, and the list of serious crimes it enables make for voluminous headlines ${ }^{72}$ - and interesting, piecemeal regulatory efforts. For example, in June, the Missouri Securities Commission formally incorporated some common sense Bitcoin disclosure standards into a charging instrument. ${ }^{73}$ The next month, New York sought to compel

67. See, e.g., A.H. SMithers, Everything You NeEd to KNow about Buying, SELLING AND INVESTING IN BITCOIN (2013); RICHARD FORBES, BITCOIN GUIDE FOR Beginners: The Essential Beginner's Guide to Buying, Selling, and Investing in BITCOIN (2014); DEVON WilCOX, BITCOIN BEgINNER's GUIDE: EVERYTHING YOU NEED TO kNOW to BeCome Rich With BitcoIns (2014); SAM Patterson, Bitcoln BeginNer: A SteP BY STEP GUIDE TO BUYING, SELLING AND INVESTING IN BITCOINS (2013).

68. CRS Summary, supra note 1 (concluding that interested parties can readily discern the market for Bitcoins via numerous Internet sources); see, e.g., BLOCKCHAIN, http://blockchain.info/charts/market-price (last visited Oct. 21, 2014); see 17 C.F.R. $\S \S$ 242.301(b)(5)(i)-(iii), (b)(6) (2014); see also Google Search for "Bitcoin price", GoogLE, http://google.com. On August 14, 2014, one Bitcoin was valued at $\$ 516$. On October 18 , the value had dropped to $\$ 381$.

69. CRS Summary, supra note 1 , at 5.

70. See, e.g., Stephen Foley, Bitcoin endorsed by top hedge fund manager,FINANCIAL TiMES (Oct. 24, 2013, 6:46 PM), http://www.ft.com/cms/s/0/5e972afe-3cce-1l le3-a8c400144feab7de.html\#axzz3DDC12wvT.

71. See, e.g., BiTSTAMP, https://www.bitstamp.net (last visited July 25, 2014); see also Complete List of Bitcoin Exchanges, 70+ Sites, supra note 61.

72. See Thompson, supra note 62 (detailing the demise of the world's largest Bitcoin exchanges amidst $\$ 64$ million in debts, halted investor withdrawals, and fear of hackers). Later that day, it was reported that the CEO of a separate Bitcoin exchange had apparently committed suicide. Michael Gray, Bitcoin firm CEO found dead after 'suicide, ' N.Y. POST (Mar. 5, 2014, 9:34 AM), http://nypost.com/2014/03/05/bitcoin-firm-ceo-found-dead-insuspected-suicide/.

73. See, e.g., The Missouri Complaint, 2014 Mo. Sec. LEXIS 12, *3 (2014). In the Complaint, the Missouri Securities Commission expressly faulted the defendants ("Virtual Miners") for not disclosing, among others, the following facts:

- Virtual currencies are not backed by a central bank and are not insured;

- Virtual currencies can be hacked or stolen with little or no recourse;

- There is no way to reverse a virtual currency transaction;

- Virtual currencies are highly volatile; and

- The liquidity of virtual currencies may be highly dependent upon the growth and 
registration of, among other enterprises, all Bitcoin exchangers (but not Miners). ${ }^{74}$ Regardless of individualized approaches, it is universally clear that the demise of each Bitcoin "exchange" leaves a finite amount of Bitcoins unrecoverable, and a new limitless class of victimized investors. ${ }^{75}$ It is highly doubtful that such investors appreciated the risks they were undertaking.

\section{The Language of Bitcoin Exchange Sites}

Despite the SEC's strict enforcement of relevant requirements, a review of the marketing employed by those touting Bitcoin Exchange Sites reveals their questionable, unedited use of the concept of registered stock exchanges:

If you're looking to buy or trade Bitcoin, for either the sovereign currency of your country or for other digital currencies, the place to do it is at a Bitcoin exchange. An exchange, for centuries known as a bourse, is in its basic form a market organized for the purpose of buying and selling investments, currencies and other financial instruments. In days gone by, the buying and selling on an exchange was done on the floor of the exchange via an open outcry system with agents for buyers and sellers shouting and using hand signals to convey information about buy and sell orders. Nowadays, open outcry is virtually extinct ... ${ }^{76}$

Individual Sites may be much more indirect in their reference to stock exchanges but impressively blunt in their solicitations:

How to Buy Bitcoins?

First thing you need to do is transfer some money into your ... account. In order to do this you must be logged in to your ... account, go [sic] to your deposit section and select preferred method of transferring funds. You will be given a unique 11 digit reference code and our account information where your funds must go. Once we receive your deposit we will credit your account and then you can start purchasing $[\mathrm{B}]$ itcoins right away. ${ }^{77}$

acceptance of thevirtual currency market.

Id. at *8-10 n. 64 .

74. See Weinberger, infra note 330; Jackson, infra note 331.

75. Abel Avram, BitCoins Lost, MongoDB and Eventual Consistency, INFo QUEUE (Apr. 24, 2014), http://www.infoq.com/news/2014/04/bitcoin-banking-mongodb (describing the loss of half-of-a-million dollars of Bitcoins to a hacker/hackers of an exchange named "Flexcoin" on March 2, 2014). Days later, an exchange named "Poloniex" lost 12.3\% of its Bitcoins to the same crime.Id.

76. See Complete List of Bitcoin Exchanges, 70+ Sites, supra note 61.

77. BITSTAMP: How to BUY BiTCons http://www.bitstamp.net/help/how-to-buy (last 
Elsewhere on the same Site appears the explanation of its limited matching role appears:

Are you selling [B]itcoins?

No. We are providing a service. You are always buying [B]itcoins from another individual who is selling them. All we do is provide a safe and simple environment to trade. We guarantee that buyers get their bitcoins and sellers get their money at agreed (sic) price. ${ }^{78}$

Furthermore, some exchanges provide a half-market, offering only to sell Bitcoins:

We are sorry, but... [w]e do not offer any refunds on coins purchased, even if we have not sent them out yet. We may be in a position to buy back your coins at the current market prices. We can also direct you to some great alternative ways to spend your coins. ${ }^{79}$

Particularly noteworthy are the steps some exchanges will take to assist with the first-time purchase of Bitcoin. Some Sites selling Bitcoin require the user to have his own digital wallet, ${ }^{80}$ but others highlight their creation of a digital wallet for customers (while also highlighting a buy/sell feature). ${ }^{81}$ Often, the buy and sell transactions take time, necessitating the holding of Bitcoins pending purchase, ${ }^{82}$ further, some Exchange Sites offer to act indefinitely as repository for the purchaser ${ }^{83}$ Certain Exchange Sites live up to the name and offer the visitor a look at a pending "order book" displaying bids to buy and offers to sell. ${ }^{84}$ The Sites offering a look at the pending order book normally include a visual tool (i.e., a graph covering the period of the last few months). Often, there is no meaningful information explaining which or how

visited July 25, 2014).

78. BITSTAMP: FAQ, http://www.bitstamp.net/faq (last visited July 25, 2014).

79. EXPRESSCOIN: FAQ, http://www.expresscoin.com/faq. The site offers a photo gallery of its nine employees-identified by first name only-and a contest awarding a percentage of a Bitcoin based upon a contestant's ability to predict the future market price of Bitcoin See EXPRESSCOIN: PRICES, http://www.expresscoin.com/prices (last visited Aug. $9,2014)$.

80. EXPRESSCOIN, http://www.expresscoin.com (last visited Nov. 10, 2014).

81. E.g., CoINBASE, https://coinbase.com (last visited Oct. 20, 104). Among other services, Coinbase offers digital wallets linked to the user's bank account.

82. SeeFrequently Asked Questions, BITSTAMP, http://www.bitstamp.net/faq/ (last visited July 25, 2014) (noting that receipt of wire transfers and conversion of funds to U.S. dollars can take two to five business days).

83. See, e.g., UNOCOIN, http://www.unocoin.com (last visited Oct. 22, 2014) (greeting the user with the message its self-description of a "Simple, Secure and Seamless Way to Store, Buy, and Sell Bitcoins in India").

84. See, e.g., Order Book, BITSTAMP, www.bitstamp.net/market/order_book (last visited July 25, 2014). 
many merchants accept Bitcoin.

Significantly, because these websites are not serving member organizations (like traditional stock exchanges) ${ }^{85}$ customers must create accounts with the sponsoring entity. ${ }^{86}$

\section{Where the SEC Has/Has Not Addressed Bitcoin}

To be sure, there have been calls for the SEC to simply define Bitcoin as a security. ${ }^{87}$ However, the Commission is presently playing it coy with its efforts to match the threat. While it has been noted that the e-phenomena does not neatly fit within SEC jurisdiction, ${ }^{88}$ the agency has concomitantly warned American investors of extreme volatility in the Bitcoin market. ${ }^{89}$ Commission Chair Mary Jo White has stopped short of committing resources to investigating Bitcoin's role as a "security" but promised a case-by-case review of circumstances in which promoters tout companies investing in Bitcoins. ${ }^{90}$ Meanwhile, journalists - either directly or indirectly - have consistently sounded the trumpet heralding Bitcoin imitators ${ }^{91}$ and, ironically, new middlemen to commerce. ${ }^{92}$

On occasion, the Commission has asserted jurisdiction over promotions centering on Bitcoin. The Shavers ${ }^{93}$ case from 2013 (which resulted in a settlement) merely focused on a Ponzi scheme accepting Bitcoin as an investment. ${ }^{94}$ Later in 2013, a federal judge sustained a Commission complaint against alleged Ponzi schemers utilizing

85. The modern stock exchange is typically a member organization requiring "trading licenses" or other attributes of membership See generally N.Y.Stock Exch. Rule 300, available at http://nyserules.nyse.com/nyse/rules/nyse-rules/chp_1_4/default.asp.

86. See, e.g., BITSTAMP: FAQ, supra note 78.

87. See Yang, supra note 24, at 109.

88. See generally Henning, supra note 5.

89. See generally Greene, supra note 66.

90. Dimitri Nemirovsky \& Bryan I. Reyhani, Why Financial Services Firms Should Prepare For Bitcoin, LAw360, (Dec. 11, 2013, 1:31 PM ET) [hereinafter Why Financial Services Firms Should Prepare For Bitcoin], available at www.mlawfirm.com/2013/12/11/why-financial-services-firms-should-prepare-for-bitcoin.

91. See Gray, supra note 2 ("Following Bitcoin, all sorts of junior crypto-currencies have popped up, mushroom-like, across the web. There's litecoin, namecoin, novacoin, worldcoin, quarkcoin, feathercoin, alphacoin to name only several out of thousands.").

92. See, e.g., Robert McMillan, The Two Sides Of Bitcoin, WIRED (Apr. 2014), available at ProQuest 1514439150 (describing the effort to create a "PayPal for [B]itcoin," gathering a " 0.5 percent charge anytime anyone converted dollars to [B]itcoins or vice versa").

93. SEC v. Shavers, No. 4:13-CV-6, 2013 WL 4028182 (E.D. Tex. Aug. 6, 2013).

94. Id. at *1. 
Bitcoin. ${ }^{95}$ Months ago, an SEC press release touted charges against the co-owner of "two Bitcoin-related websites for publicly offering shares in the two ventures without registering them." ${ }^{96}$ But that recent action represents another pooling arrangement, rather than a swipe at Bitcoin itself (or any entity serving as "exchange" therefor). ${ }^{97}$

Interestingly, the latest SEC disclosure of its broad priorities is bold. In early summer 2014, the Commission prioritized its role in overseeing "intermediation," or where parties stand between buyer and seller of securities. ${ }^{98}$ In forceful language, the SEC Chair confirmed the Commission's willingness to combat a burgeoning class of middlemen, reminding that new situations require some creative thinking:

To complicate things further, the neat lines that Congress drew in 1934 have not resulted in models of intermediation that are clear-cut or uniform across securities markets. Most obviously, the functions of broker and dealer often have been combined - there is a reason we call them "broker-dealers." The conflict between investors' interests and the intermediary's interests that can be created by this dual role has been a source of serious concern since the SEC was created. ${ }^{99}$

The Chair likewise committed the SEC's tools to protecting investors against the "powerful forces" of technology and competition "in every securities market." 100 Yet, the SEC's planned response to Bitcoin remains amorphous.

95. Alyssa Newcomb, SEC Can Pursue Case Against Alleged Bitcoin Ponzi Schemer, Federal Judge Says, ABC News ONLINE (Aug. 8, 2013 6:00 AM), http://abcnews.go.com/blogs/business/2013/08/sec-can-pursue-case-against-alleged-bitcoinponzi-schemer-federal-judge-says/.

96. Press Release 2014-111, SEC, SEC Charges Bitcoin Entrepreneur With Offering Unregistered Securities (June 3, 2014), available athttp://www.sec.gov/News/PressRelease/Detail/PressRelease/1370541972520\#.VGF9Qvn F83k.

97. See Co-owner of bitcoin-linked sites settles SEC case, THE SALT LAKE TRIBUNE (June 3, 2014), available at http://www.sltrib.com/sltrib/money/58022860-79/bitcoin-secowner-securities.html.csp (noting a Commission settlement with "a prominent bitcoin proponent" for over $\$ 50,000$ based upon alleged sales of unregistered shares paid for with Bitcoin).

98. Mary Jo White, Chairwoman, SEC, Intermediation in the Modern Securities Markets: Putting Technology and Competition to Work for Investors (June 20, 2014), available

http://www.sec.gov/News/Speech/Detail/Speech/1370542122012\#.VGEDSvnF83k

(elaborating on the prior promise to study and address the threat posed by "high-frequency trading" and clarifying that the "securities" market includes the "fixed income" market).

99. Id. at 3 .

100. Id. at 13 . 
Thus, by late summer 2014, amidst the exchange closings and lost Bitcoins and lawsuits, there nonetheless existed certain truths about the Bitcoin market. First, Bitcoin's presence is widespread and resilient. Second, Bitcoin's varied uses and users have expanded exponentially, beyond expectations. Third, Bitcoin "exchanges" are making some highly visible yet sometimes unsupportable claims (and, at times, acting much more like stock promoters than market centers). Finally, no regulator is effectively addressing the investment potential.

\section{EXISTING REgUlation OF "EXChANGES"-AllowING No RAIDS ON THE CASTLE}

A study of the legal definition of a "stock exchange" confirms that great discretion resides with the Commission as an expertise agency, and that the agency's relevant interpretations have been loudly sounded.

\section{A. What is an "exchange"?}

The effect of stock exchanges on a national economy is well documented. A famous litigation from the 1960 s provided this salutary summary of the interplay between centralized market centers and their regulation:

To the public exchanges are an investment channel which promises ready convertibility of stock holdings into cash. The importance of these functions in dollar terms is vast .... [B]ecause such transactions are often regarded as an indicator of our national economic health, the significance of the exchanges in our economy cannot be measured only in terms of the dollar value of trading. ... It was, therefore, the combination of the enormous growth in the power and impact of exchanges in our economy, and their inability and unwillingness to curb abuses which had increasingly grave implications because of this growth, that moved Congress to enact the Securities Exchange Act of 1934. ${ }^{102}$

The referenced statutory definition of "exchange" is thus dauntingly broad:

The term "exchange" means any organization, association, or group of persons, whether incorporated or unincorporated, which constitutes, maintains, or provides a market place or facilities for bringing together purchasers and sellers of securities or for otherwise performing with

101. For purposes of clarity, entities formally recognized by the SEC as registered stock exchanges are connoted herein with a capital "E."

102. Silver v. N. Y. Stock Exch., 373 U.S. 341, 349-52 (1963) (upholding selfregulatory efforts challenged by an NYSE member). 
respect to securities the functions commonly performed by a stock exchange as that term is generally understood, and includes the market place and the market facilities maintained by such exchange. ${ }^{103}$

That definition in the 1934 Act has stood for decades. To be sure, wholesale reform of the stock exchange has been rare, even in times of near-demise. ${ }^{104}$ While $\S 19$ of the 1934 Act, which governs the SEC's supervisory role, did not initially integrate the Commission into exchange rulemaking or internal discipline, ${ }^{105}$ since the storied 1975 amendments to the federal securities laws, ${ }^{106}$ the agency has been vastly empowered. Specifically, the Commission is authorized to, among other things, approve exchange rules in advance, review disciplinary actions, regulate commission rates and "eliminate any other exchange rules which impose[] unwarranted restraints on competition."107

The related SEC releases interpreting the scope of the definition of "exchange" are brief but evidence certainty. Much of this existing guidance stems from a series of cases initiated by the Chicago Board of Trade ("BOT"). Approximately two decades ago, that entity asked the SEC to determine that a new proprietary trading system that traded options on government securities and was utilized by a broker-dealer (the "Delta System") was required to register with the SEC. The BOT request had been prompted by the Commission's decision to take "No Action" against the operator of the Delta System on the grounds that

103. Section 3(a)(1) of the Securities and Exchange Act of 1934, 15 U.S.C. $\S$ $78 \mathrm{c}(\mathrm{a})(1)(2012)$.

104. See, e.g., Joel Seligman, The Transformation of Wall Street 589-604 (3d ed. 2003). Professor Seligman was quite pointed in his summary of SEC compromise on comprehensive exchange reform:

The Commission might have been wiser to use the occasion of the October 1987 crash as the means to galvanize congressional support for a new special study ofthe securities markets.... Instead, during [Chairman] Breeden's chairmanship, the SEC initiated a staff report ultimately entitled [sic] Market 2000: An Examinationof Current Equity Market Developments. When published in early 1994, it offered a series of incremental proposals to refine securities trading, but little of the broadcontext and general examination of securities market structural issues that had characterized the Commission's earlier effort.

Id. at 604; see also J. Scott Colesanti, Other People's Volatility: A Call for Rules that More Equitably Stabilize the Stock Market, 37 U. DAYTON L. REV. 1 (2013). 2006).

105. Thomas lee hazen, Principles of Securities Regulation328-29 (2d ed.

106. John DOWNES \& JoRdan Elliot GoOdman, Dictionary of Finance AND INVESTMENT TERMS 542 (5th ed. 1998) (describing how the Securities Acts Amendments of 1975 propelled the notion of a national market, thus focusing on, among other things, codified rules governing securities transfer and settlement, and the formal prohibition of fixed commission rates for securities purchases and sales).

107. Id. at 329 . 
proprietary systems (i.e., non-exchanges) that "offer to participants the capacity to execute automatically transactions based on derivative pricing" had not yet evolved into "interdealer quotation or transaction mechanisms" fielding quotations on a consistent basis." 108 In the view of the SEC in 1989, these systems need not register as exchanges. ${ }^{109}$

Upon judicial review, the Seventh Circuit called the Delta System "neither fish nor fowl" and could not (or simply would not) declare the Delta System an "exchange." 110 The Seventh Circuit panel noted that it "could not find a single case under [1934 Act] §3(a)(1)" detailing factors for "sorting a trading apparatus into the "exchange' bin." 111 The case was thus remanded for a formal ruling by the SEC on the question of exchange status. ${ }^{112}$

On remand, the SEC fleshed out its position that the Delta System was not an exchange:

In conducting [the $\S 3(\mathrm{a})(1)$ ] analysis, the central focus of the Commission's inquiry should be whether the system is designed, whether through trading rules, operational procedures or businessincentives, to centralize trading and provide buy and sell quotations on a regular or continuous basis so that purchasers and sellers have a reasonable expectation that they can regularly execute their orders at those price quotations .... ${ }^{113}$

Finding no standard quotations or continuous trading, the SEC again refused to declare the Delta System an exchange. The SEC's final determination was challenged by the BOT, leading to a second Seventh Circuit decision on the matter. ${ }^{114}$ Calling the system "[a]n ingenious device for facilitating the purchase and sale of securities," "15 the Second BOT Decision noted that the Delta System lacked, among other things, members, a trading floor, and overseers (i.e., specialists or market-

108. Propriety Trading Sys., Exchange Act Release No. 26,708, 54 Fed. Reg. 15429 (Apr. 11, 1989); see DOWNES \& GoODMAN, supra note 106, at 395 (an SEC "No Action Letter" is a letter requested of the SEC wherein the Commission agrees to not take disciplinary action in response to specific activity).

109. Propriety Trading Systems, supra note 108.

110. Bd. of Trade of Chi. v. SEC (First BOT Decision), 883 F.2d 525, 535 (7th Cir. 1989).

111. Id.

112. Id. at 536.

113. Proprietary Trading Sys., Exchange Act Release No. 27,611, 55 Fed. Reg. 1890 (Jan. 12, 1990).

114. Bd. of Trade of Chi. v. SEC (Second BOT Decision), 923 F.2d 1270 (7th Cir. 1991).

115. Id. at 1271 . 
makers) ${ }^{116}$ Noteworthy was the court's emphasis on the Commission's broad discretion in interpreting the elastic $\S 3$ definition. ${ }^{117}$ Finally, the court reminded that the primary focus of the SEC inquiry is "a threat to the safety of investors;" 118 also paramount is the consideration of whether exemption from registration creates "regulatory gaps." 119 Overall, while the Board of Trade cases ultimately held that the novel trading system need not be registered, the case resonated loudest in clarifying the Commission's unilateral discretion as an expertise agency in defining stock exchanges. ${ }^{120}$

The demands of registration placed on such entities help us further understand what makes an "exchange." Specifically, the relevant SEC "Form 1" requests specific information in the following areas:

- Corporate structure, ${ }^{121}$

- Affiliated trading partners, ${ }^{122}$

- Manner of operation of the trading system (including the fees and hours of operation), ${ }^{123}$

- Audited financial statements, ${ }^{124}$ prepared by an independent consultant in conformance with GAAP, ${ }^{125}$

116. Id. at 1272 .

117. Id. at $1272-73$ (noting "there is enough play in the statutory joints")

118. Id. at 1273 .

119. Second BOT Decision, 923 F.2d at 1273.

120. See John C. Coffee, JR. \& Hillary A. Sale, Securities Regulation Cases ANDMATERIALS 588-89 (12th ed. 2009) [hereinafter COFFEE \& SALE] (explaining that the SEC "stuck to its guns" on remand of the first Delta case-i.e., again found no exchange present-as evidenced by the language of 1934 Act Release No. 27611 from January 12, 1990).

121. See generally SEC Form 1 Exhibits "A"-"C," available at http://www.sec.gov/about/forms/forml.pdf [hereinafter Form 1]; Comm'n Notice: Nasdaq Stock Market, Inc., Files Application for Registration as a Nat'1 Sec. Exch., Exchange Act Release No. 44,396, 2001 WL 629346 (June 7, 2001), available at http://www.sec.gov/rules/other/34-44396.htm [hereinafter Nasdaq Application].

122. Form 1, supra note 121, at Exhibit "D."

123. Id. at Exhibit "E."

124. Id. at Exhibits "G" and "I."

125. DOWNES \& GOODMAN, supra note 106, at $234-35$ (the United States' Generally Accepted Accounting Principles ("GAAP") are "conventions, rules and procedures that define accepted accounting practice, including broad guidelines as well as detailed procedures." GAAP principles are prepared by the Financial Accounting Standards Board, an independent organization); see Gretchen Morgenson, What? They Never Heard of WorldCom?, N.Y. TIMES (Mar. 20, http://www.nytimes.com/2005/03/20/business/yourmoney/20gret.html?_r=0 (quoting a chief strategist at a major Wall Street firm: "The reason you have G.A.A.P. is so investors have consistent clear information. The U.S. has always prided itself on having the most 
- Shareholders with a $5 \%$ or more ${ }^{126}$ interest, ${ }^{127}$

- Members, as well as criteria for membership, ${ }^{128}$ and

- Securities trading on the Exchange. ${ }^{129}$

Overall, the mandatory disclosure attending formal exchange status requires that the Commission and the investing public learn of "detailed information" about an Exchange and "how it proposes to satisfy the requirements of the [1934] Act." 130 Consequentially, statutory stock exchanges are finite in number, ${ }^{131}$ reasonably well understood by the industry, and policed by the SEC on many levels.

\section{B. Regulation ATS-An Accommodation with Strings Attached}

Subsequently, the technologically-enabled marketplace necessitated new regulation; in 1997, the SEC chose a familiar route (i.e., compelling new trading systems to register as broker-dealers). ${ }^{132}$

transparent financial markets."). GAAP principles are generally regarded as the most stringent accounting standards in the world. Shalala v. Guernsey Memorial Hosp., 514 U.S. 87, 101 (1995) (discussing the "conventions, rules, and procedures that define accepted accounting practice").

126. Form 1, supra note 121 , at Exhibit " $\mathrm{K}$ " (the $5 \%$ requirement is requested by Exhibit "K").

127. In response to pernicious tender offers in the 1960s, in 1968 Congress passed the Williams Act amendments to the 1934 Act. Since that time, 1934 Act $\S 13$ requires owners of $5 \%$ or more of the securities of certain public companies to file Schedule 13D ("beneficial ownership report") with the Commission. See Schedule 13D, SEC, www.sec.gov/answers/sched13.htm.(last visited Sept. 23, 2013).

128. Form 1, supra note 121, at Exhibits "L" and "M."

129. Id. at Exhibit "N."

130. Nasdaq Application, supra note 121. Nasdaq existed as a unique electronic trading platform-nonetheless squarely on the government's radar-until its formal conversion to a duly registered exchange last decade in order to complete its public offering. Id.

131. There are presently sixteen stock exchanges registered with the SEC, pursuant to $\S 6$ (a) of the 1934 Act, 15 U.S.C. §78I(a). STEPHEN M. BAINBRIDGE, INSIDER TRADING LAW AND POLICY 214 ( $2 \mathrm{~d}$ ed. 2014) ("Only listed securities may be traded on the exchange in question."); Exchanges, SEC, http://www.sec.gov/divisions/marketreg/mrexchanges.shtml, (last visited July 21,2014 ). In addition, the SEC recognizes six exchanges registered under $\S 6(\mathrm{~g})$ of the 1934 Act "for the purpose of trading security futures." $I d$.

132. Ironically, the SEC's familiar response of a prior generation-laudable as an attack on the monopolies enjoyed by traditional exchanges-is nonetheless now decried as enabling the unchecked proliferation of dark pools, which have been linked to high frequency trading. Compare JOHN G. COFFEE, JR. \& HILlARY A. SALE, SECuRItIES REGULATION 603 (12th ed. 2006) ("The SEC's historic attitude of benign neglect toward alternative trading systems was largely a product of their low volume plus the fear that close regulation would retard their evolution as competitive alternatives to the traditional markets.") with MiCHAEL LeWIS, FlaSh BOYS 112 (Starling Lawrence ed., W. W. Norton \& Co. 2014) ("Since the mid-2000s, the average trade size in the U.S. stock market had 
More specifically, the rise of proprietary trading systems and Electronic Crossing Networks ("ECNs") ${ }^{133}$ prompted the Commission's adoption of Regulation ATS (i.e., "Alternative Trading Systems") of 1997. ${ }^{134}$ While Regulation ATS did allow rivals to traditional stock exchanges, the 1934 Act definition of "exchange" remained concrete, ${ }^{135}$ and its strict application, consistently interpreted-indeed, the failure to comply with Regulation ATS is itself a violation disciplinable by the Commission. ${ }^{136}$

Further, the industry is guided on the question of whether or not to register a trading system as an exchange by the numerous requirements within Regulation ATS, which mandates maintenance of "security of automated systems," ${ }^{137}$ fair access by customers, ${ }^{138}$ registration with the SEC as a broker-dealer, ${ }^{139}$ display of all subscriber orders, ${ }^{140}$ capacity estimates, ${ }^{141}$ fees commensurate with industry practice, ${ }^{142}$ customer confidentiality, ${ }^{143}$ and record-keeping. ${ }^{144}$

Additionally, more granular regulations similarly liberally define "exchange," thus ensuring compliance with the Form 1 or Regulation ATS protocols. For example, SEC Rule $3 b-16$ has been used to support a very basic understanding of a stock exchange-a market center that matches buyers and sellers. ${ }^{145}$ Private players at home and abroad

plummeted, the markets had fragmented, and the gap in time between the public view of the markets and the view of the high-frequency traders had widened.").

133. Dana Stiffler \& Deborah Williams, ECNs Close In on NASDAQ, 3 No. 6 WALLSTREETLAWYER.COM: Sec. Elec. Age 1 (1999) ("ECNs are fully automated systems that match orders and set prices for trades. In a certain sense, an ECN functions like an electronic stock exchange."). By 1999, the number of formal ECNs tallied nine and posed a volume threat to, among others the NASDAQ. Id.

134. 17 C.F.R. \$ 242.301 (2014).

135. See, e.g., 15 U.S.C. $\S 78 \mathrm{c}(\mathrm{a})(1)$ (2012) (defining "exchange" to include any entity that "provides a market place or facilities for bringing together purchasers and sellers of securities or for otherwise performing with respect to securities the functions commonly performed by a stock exchange").

136. See, e.g., In re INET ATS, Inc., Exchange Act Release No. 53631, 2006 WL $6324802, * 1-2$ (Apr. 12, 2006) (instituting and settling disciplinary proceedings against a New Jersey broker-dealer that allegedly failed to comply with "fair access" requirements triggered by attainment of $20 \%$ trading volume in stocks between 2002 and 2003).

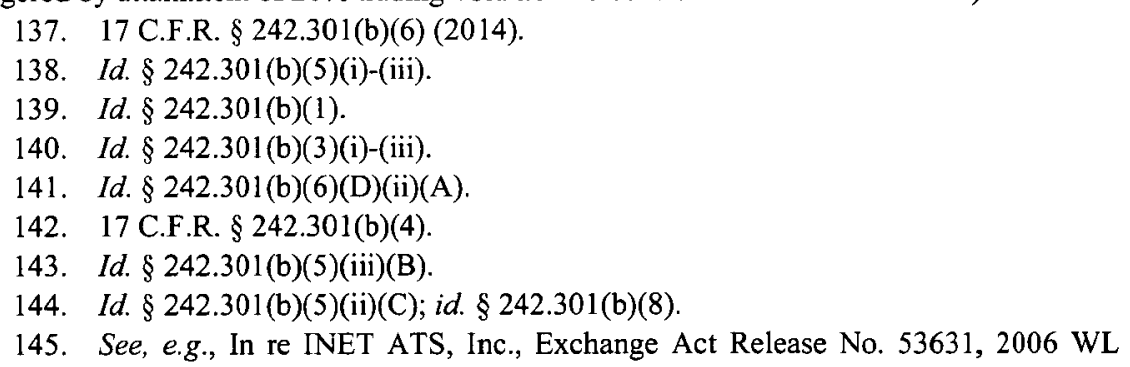


understand that the consistency of this interpretation warrants a ruling from the SEC whenever the call becomes close. To that end, in recent years, exchanges dabbling in currency speculation ${ }^{146}$ and trades among their shareholders ${ }^{147}$ have conservatively requested a "No Action Letter" from the Commission. Of note as of late, entities operating trading systems functioning as dark pools ${ }^{148}$ or other quasi-exchanges have been required to register either as a broker-dealer or exchange with the Commission. ${ }^{149}$

Significantly, a review of SEC discipline of exchanges yields numerous instances of traditional exchanges failing in regards to their listing of traditional securities, ${ }^{150}$ but no such discipline of an alternative exchange (i.e., one matching investors in nontraditional securities).

938783 (Apr. 12, 2006):

An ATS is any organization, association, person, group of persons, or system: (a) that constitutes, maintains or provides a market place or facilities for bringing together purchasers and sellers of securities or for otherwise performing with respect to securities the functions commonly performed by a stock exchange ... and (b) that does not: (i) set rules governing the conduct of subscribers other than the conduct of such subscribers' trading on such organization... ; or (ii) discipline subscribers other than by exclusion from trading.

146. See Channel Islands Stock Exchange, SEC No-Action Letter, No Action, 2002 WL 31101733, at *2 (Sept. 6, 2002) (permitting "services with respect to transactions in, investments of all kinds, whether direct or derivative, including financial instruments and currencies").

147. See Letter from Ross Kaufman to Paul Dudek, SEC, at 3 (July 14, 2014), available at www.sec.gov/divisions/corpfin/cf-noaction/2014/klabin-071414-3a9incoming.pdf (interpreting $\S 3(\mathrm{a})(9)$ of the Securities Act as exempting transactions with existing security holders "where no commission or other remuneration is paid or given directly or indirectly for soliciting such exchange").

148. "Dark pools" are private stock exchanges operated by registered broker-dealers to provide anonymity for institutional investors. They are notorious for their lack of transparency. Elvis Picardo, CFA An Introduction to Dark Pools, INVESTOPEDIA, www.investopedia.com/articles/markets/050614/introduction-dark-pools.asp (last visited Oct. 18, 2014).

149. Regulation of Exchs., Exchange Act Release No. 38672, 1997 WL 276278, at *35 (May 23, 1997).

150. See, e.g., In re Nat'l Assoc. of Sec. Dealers, Exchange Act Release No. 37538, 1996 WL 447193, at*1 (Aug. 8, 1996) (censuring and imposing remedial measures on the Nasdaq market for failing to investigate unlawful trading); N.Y. Stock Exch., Inc., Exchange Act Release No. 41574, 1999 WL 430863, at*1 (June 29, 1999) (censuring the New York Stock Exchange, Inc. ("NYSE") for failing to detect unlawful proprietary trading by certain of its member firms); N.Y. Stock Exch., Inc., Exchange Act Release No. 51524, 2005 WL 840452, at *1 (Apr. 12, 2005) (censuring the NYSE for failing to detect/investigate unlawful member trading); N.Y. Stock Exch. LLC, Exchange Act Release No. 67857, 2012 WL 4044880 , at *3 (Sept. 14, 2012) (censuring the NYSE for faulty distribution of market data); N.Y. Stock Exch. LLC, Exchange Act Release No. 72065, 2014 WL 1712113, at *2 (May 1, 2014) (censuring and fining the NYSE \$4.5 million for failing to establish/enforce rules governing error account trading). 


\section{Application of "Exchange" Law to Bitcoin Exchange Sites}

In sum, the scant case law on the scope of SEC discretion reflects suits initiated by traditional stock exchanges fearful of upstart competition (i.e., plaintiffs with a true financial interest in the outcome). That case law, while admitting some statutory ambiguity, ${ }^{151}$ confirms unilateral SEC discretion in labeling "exchanges" based upon evaluation of the following factors:

1. Whether the nontraditional exchange matched customer orders in securities;

2. Whether the nontraditional exchange poses a threat to investors;

3. Whether the decision not to require registration as an exchange would result in regulatory gaps; and

4. Whether the entity exhibits traditional exchange activities such as rules of membership and continuous quoting and trading. ${ }^{152}$

The wide variety of Bitcoin Exchange Sites precludes a meaningful statutory analysis: some Sites only sell Bitcoin, ${ }^{153}$ some match customer orders, ${ }^{154}$ some continuously display an order book, ${ }^{155}$ and some hold the Bitcoins of customers indefinitely. ${ }^{156}$ Moreover, most entities currently attempting to serve as Bitcoin "exchanges" exhibit none of the capacities for delivering all of the information called for by Form 1 or the protocol established by related exemptive measures such as Regulation ATS or SEC Rule 3b-16 (i.e.,fair access, uniform fees, audited financials, or display of all customer orders ${ }^{157}$ ). The press may have done all a tremendous disservice in labeling all entities offering some form of entrance into the Bitcoin market as "exchanges;" regardless, the threat posed by this hodgepodge is no less real.

Specifically, the threat is delivered (often from abroad, via the Internet) through advertisements and communications revealing a bastardization of the notion of the modern stock exchange. These advertisements often lack in accompanying transparent quote display, a lack of depth to quotes, and information on entity membership. ${ }^{158}$ The newness of the enterprises and ease of entry into the field renders

151. Second BOT Decision, 923 F.2d 1270, 1273 ("Of course, if the statute [i.e., the 1934 Act] were unambiguous, the Commission would have to bow.") (citations omitted).

152. See supra notes $102-109$ and accompanying text.

153. See EXPRESSCOIN, supra note 80.

154. See BitsTAMP: FAQ, supra note 78.

155. See Order Book, supra note 84.

156. See supra notes $82-83$ and accompanying text.

157. See supra notes 137-144 and accompanying text.

158. See generally supra notes $76-86$ and accompanying text. 
considerations of recordkeeping and capacity estimates irrelevant. In sum, entities that either are or are not serving as a permanent market are offering Bitcoins to the unsophisticated in return for a transfer of money, repeatedly highlighting the investment potential of a Bitcoin purchase. ${ }^{159}$ Often, the individual so solicited is not first offered basic facts about Bitcoin or the entity sponsoring the website; however, the daily consensus price for a sole Bitcoin is referenced (and freely available elsewhere on the Internet). ${ }^{160}$ Moreover, that well-publicized daily conversion rate-as is apparent after only moments searching on the Internet-has risen over $50 \%$ this year alone. ${ }^{161}$

Clearly, the status quo is in need of regulation. ${ }^{162}$ Investigating Bitcoin Exchange Sites for their possible violation of provisions of the Securities Acts would work to quell fears that Bitcoin is growing unabated while reminding the industry that compliance dollars are wellspent. Any second-guessing of this goal is readily met by the tales of woe that have already befallen Bitcoin "investors." In early 2014, Mt. Gox, the largest Bitcoin exchange, fell prey to the theft of Bitcoins valued at $\$ 400$ million and filed for bankruptcy in two nations; ${ }^{163}$ days later, the world learned from headlines of the suicide of the head of a separate Bitcoin exchange. ${ }^{164}$ Smaller exchanges have met similar

159. See, e.g., What is Bitcoin?, BITSTAMP, https://bitstamp.net/help/what-is-bitcoin (last visited Sept. 10, 2014) ("If you have some Bitcoins saved, you can make them more valuable by using Bitcoins. Using Bitcoins increases their demand which in turn increases the value of your saved Bitcoins.").

160. Google Search for "Bitcoin price", Google, http://google.com; BitsTAMP, http://www.bitstamp.net (last visited July 25,2014 ) (for example, the conversion rate for July 25,2014 was $\$ 602.03$ per Bitcoin).

161. See, e.g., Bitcoin Market Price (USD), BLockCHAIN.INFo, http://www.blockchain.info/charts/market-price (last visited Sept. 10, 2014) (daily pricing data) andDouble-Digit Yield, CROWDABILITY, http://landing.crowdability.com/the-nextbitcoin (last visited Sept. 10,2014) (stressing Bitcoin's meteoric 1,946\% rise in price during 2013).

162. See Andrew Ramonas, CFPB Gets Real About Bitcoin Risks, Legal Times (Aug. 11, $2014 \quad 2: 43 \quad$ PM), http://www.nationallawjournal.com/legaltimes/id=1202666454383/CFPB-Gets-Real-AboutBitcoin-Risks?slreturn=20140810104117 (summarizing the announcement by the young Consumer Financial Protection Bureau that consumers should be wary of Bitcoin-which "can cost more to use than cash or credit cards"- and utilize the federal agency's dedicated link to report complaints).

163. Bitcoin: More than a Bit Risky, Fin. Indus. REgUlatory Auth. (May 7, 2014), www.finra.org/Investors/ProtectYourself/InvestorAlerts/FraudsAndScams/P456458. The Tokyo-based Bitcoin exchange ceased operations on February 24, 2014. Id. It then filed for bankruptcy in Japan days later, and in the U.S. on March 10). Id. See also, for example, Greene, supra note 11.

164. See Thompson, supra note 62. 
terminal fates. In March 2014, a Canadian exchange announced it was closing after Bitcoins valued at $\$ 600$ thousand were electronically pilfered. The same month, a Chinese exchange named Vircurex announced account freezes after it was victimized by cyber-attacks. ${ }^{165}$

To be sure, Bitcoin Exchange Sites pose a threat to investors that currently flourishes in a regulatory vacuum. But those entities often exhibit so few of the characteristics of statutory stock exchanges as to render the comparison absurd-indeed, one website even offers to help enthusiastic entrepreneurs start their own Bitcoin "exchange." 166

The more rational analysis of Bitcoin exchange sites would thus appear to be as an offering of a security as defined by the Securities Acts. The relevant case law is voluminous and decidedly in support of an expansive definition; the accompanying policy justifications comport with the threat presently posed. Under either a legal or policy approach, the key determination would appear to be whether the Bitcoin exchange serves as originator of a money-making scheme ("Promoter") and its customer as passive contributor of funds thereto ("Investor"). In short, evidence of a passive, interdependent relationship would remove any jurisdictional hurdle to the SEC's assertion of jurisdiction. As trends in the governing case law indicate, that fact-specific inquiry often boils down to considerations of relative expertise.

\section{ARMING THE White KNIGHT}

\section{A. What is a "Security"?-The Howey Case and Its Progeny}

The SEC's activism in finding novel financial arrangements to be securities is legendary; moreover, with an eighty-year head start, the agency is aptly experienced at litigation aimed at expanding the definitional or registration sections of the securities laws, even in the absence of a complainant. ${ }^{167}$ Specifically, the Howey decision of 1946 began a ceaseless period of brashly applying the Securities Acts to

165. Greene, supra note 11.

166. LOCALBITCOINS.COM, https://localbitcoins.com (last visited Sept. 10, 2014) (offering to help site visitors "[f]ind local bitcoin exchangers in your country or start your own bitcoin exchange ... for profit").

167. See, e.g., SEC v. W.J. Howey Co., 382 U.S. 293, 301 (1946); SEC v. Koscot Interplanetary, Inc., 497 F.2d 473 (5th Cir. 1974); and SEC v. Glenn W. Turner Enters. Inc., 474 F.2d 476, 482 (9th Cir. 1973) (these three famed cases were brought without evidence of a customer complainant); see alsoThe Investor's Advocate: How the SEC Protects Investors, Maintains Market Integrity, and Facilitates Capital Formation, SEC, http://www.sec.gov/about/whatwedo.shtml\#.VBBmi_ldWNg (last visited Sept. 10, 2014) (describing the individual investor as "[o]ne of the major sources of information on which the SEC relies to bring enforcement action."). 
nonconventional securities - an ever-growing list of investments the First Circuit has coined "a kaleidoscopic assortment of pecuniary arrangements that defy categorization." 168 This expansive reading of the statute is buttressed by court decisions noting the lack of other regulatory remedies - the Supreme Court has even expressly tilted the scales in favor of finding a security when the instruments in question "would escape federal regulation entirely if the [Securities] Acts were held not to apply." 169 Most importantly for present purposes, the application of the securities laws to purely private transactions is unquestioned, ${ }^{170}$ absent a statutory exemption, when the arrangement in question satisfies the time-honored test set forth by the Court in Howey. ${ }^{171}$

In Howey, tourists bought slices of land within an orange grove, presumably for investment purposes. ${ }^{172}$ In addition to a warranty deed to the fractional interest, the tourists were offered an installment payment plan and a land service contract; the SEC successfully argued that the three documents in tandem were tantamount to an investment contract as included in section 2 of the 1933 Act. ${ }^{173}$ The Supreme Court

168. SEC v. SG Ltd., 265 F.3d 42, 44, 47 (1st Cir. 2001) (denying defendants' motion to dismiss).

169. Reves v. Ernst \& Young, 494 U.S. 56, 67-69 (1990) (finding farm cooperative demand notes to be securities after analysis under the Second Circuit's "family resemblance" test, used to identify commercial paper).

170. Landreth Timber Co. v. Landreth, 471 U.S. 681, 697 (1985) (finding an investment contract-and thus a security-within a written agreement to purchase a lumber mill).

171. W.J. Howey Co., 328 U.S. at 301 ("The test is whether the scheme involves an investment of money in a common enterprise with profits to come solely from the efforts of others.").

172. Id. at 296 ("The purchasers for the most part are non-residents of Florida.... Many ... are patrons of a resort hotel owned and operated by the Howey Company in a scenic section adjacent to the [citrus] groves.").

173. To wit, $\S 2$ (a) of the 1933 Act reads in relevant part as follows:

The term "security" means any note, stock, treasury stock, security future, securitybased swap, bond, debenture, evidence of indebtedness, certificate of interest or participation in any profit-sharing agreement, collateral-trust certificate, preorganization certificate or subscription, transferable share, investment contract, voting-trust certificate, certificate of deposit for a security, fractional undivided interest in oil, gas, or other mineral rights, any put, call, straddle, option, or privilege on any security, certificate of deposit, or group or index of securities (including any interest therein or based on the value thereof), or any put, call, straddle, option, or privilege entered into on a national securities exchange relating to foreign currency, or, in general, any interest or instrument commonly known as a "security", or any certificate of interest or participation in, temporary or interim certificate for, receipt for, guarantee of, or warrant or right to subscribe to or purchase, any of the foregoing. 
agreed, and the operators of the grove were forced to register their collective offer as a security. ${ }^{174}$ The case demonstrated the SEC's will to tackle, among other things, nonconventional investments in a part of the country that had been widely criticized for real estate speculation. ${ }^{175}$ The famed Supreme Court decision explained that operative section 5 of the 1933 Act, which requires SEC registration of all "securities,"176 is violated absent any showing of intent (i.e., it can be violated even as a result of "bona fide mistake"). ${ }^{177}$ Further, the concluding words of the majority opinion declared, "[t]he statutory policy of affording broad protection to investors is not to be thwarted by unrealistic and irrelevant formulae." ${ }^{\prime 178}$ Additionally, the Howey test ensured that substance would triumph over form; ${ }^{179}$ consequentially, the name assigned to an investment ${ }^{180}$ and even the act of registering a deal as a security with regulators ${ }^{181}$ became ancillary to a determination of coverage by the Acts.

15 U.S.C. $\S 77 \mathrm{~b}(\mathrm{a})(1)$ (2012). The same definition in appears in the 1934 Act, with very limited variance. 15 U.S.C. $\$ 78 \mathrm{c}(\mathrm{a})(10)(2012)$; see also Int'l Bhd. of Teamsters v. Daniel, 439 U.S. 551, 556 n.7 (1979) (citing, inter alia, Tcherepnin v. Knight, 389 U.S. 332, 342 (1967) for the proposition that it has long been held in federal courts that "the coverage of the two Acts may be regarded as the same").

174. W.J. Howey Co., 328 U.S. at 301. Separately, the Howey decision, while noting that the term "investment contract" was undefined by the 1933 Act, concurrently noted that it was "common in many state "blue sky' laws" and had been "broadly construed by state courts so as to afford the investing public a full measure of protection."Id. at 298.

175. See Jesse Colombo, The 1920s Florida Real Estate Bubble, TheBUBBLEBuBBLE.COM (June 26, 2012), http://www.thebubblebubble.com/floridaproperty-bubble.

176. 1933 Act Section 5 is a difficult read, at best. See ThOMAS LeE HAZEN \& DaVID L. RatNer, Broker-Dealer Regulation/Cases and Materials 22 (2003) ("Section 5 has a dual thrust .... Unfortunately, the structure of 1933 Act $\S 5$ does not clearly reflect this division; nor does it clearly reflect the distinctions between the three different periods defined by the filing date and effective date of the registration statement."). Nonetheless, the provision is steadfastly interpreted as creating dual obligations for those who would sell securities in the United States (or to U.S. investors), to wit, (1) the requirement that the security be registered with the SEC prior to its issuance, and (2) that the delivery of the related prospectus precede or accompany the sale of the security. 15 U.S.C. $\S 77 \mathrm{e}(2012)$.

177. W.J. Howey Co., 328 U.S. at 300.

178. Id. at 301 .

179. See, e.g., J. Scott Colesanti, Will the Howey Test Prize Substance Over Form?, LEXISNEXIS EXPERT COMMENTARY (Sept. 2008).

180. See, e.g., Landreth Timber Co. v. Landreth, 471 U.S. 681, 686 (1985) (“[T] fact that instruments bear the label 'stock' is not of itself sufficient to invoke the coverage of the Acts."). 1999).

181. See Great Rivers Coop. v. Farmlands Indus., Inc., 198 F.3d 685, 698 (8th Cir. 
Collaterally, Howey (along with the preceding Joiner Leasing ${ }^{182}$ high court case) evidenced the desire to apply the relatively new securities laws to instruments "that were not susceptible to trading on exchanges or in other securities markets." ${ }^{\text {"183 }}$ Finally, Howey reminded that the courts would actively further the remedial mood of the congress of 1933/1934: Justice Frankfurter had been one of the drafters of the 1933 Act, ${ }^{184}$ and yet the Court majority relegated his fears of an overexpansive reading of "security" to the decision's dissent. ${ }^{185}$

\section{B. State of the Law on Howey Elements}

Thus, despite the detailed, comprehensive list of covered arrangements populating the statutory definition, the "Howey Test" became the standard by which private arrangements did or did not come within reach of the securities laws. A universally utilized barometer, the test is frequently summarized into four conjunctive factors: ${ }^{186}$

\section{1. "An investment of money. .."}

The seminal case to interpret the required monetary investment centered on John Daniel, the unfortunate teamster who inventively attempted to bring a compulsory (but non-contributory) employee pension plan within the reach of the securities laws. ${ }^{187}$ Daniel had

182. SEC v. C.M. Joiner Leasing Corp., 320 U.S. 344, 351 (1943) (applying the statute to the sale of oil and gas leases in conjunction with the promoter's promise to drill oil test wells; holding that the reach of the 1933 Act "does not stop with the obvious and commonplace.").

183. COFFEE \& SALE, supra note 120 , at 258-59.

184. Charles R. Geisst, Wall Street: A History 228-29 (1997) ("Felix Frankfurter, of the Harvard Law School, and two assistants helped draft the final version [of the 1933 Act].")

185. To wit, Justice Frankfurter - thirteen years after helping to draft the 1933 Actexpressly objected to an elastic reading of the statutory definition of 'security' in his dissenting opinion. See id.; SEC v. W.J. Howey Co., 328 U.S. 293, 301 (1946) (Frankfurter, J., dissenting) ("I find nothing in the Securities Act to indicate that Congress meant to bring every innocent transaction within the scope of the Act simply because a perversion of them is covered by the Act.").

186. Although some courts occasionally phrase the Howey Test in three factors, the totality of required elements is consistently the same. Compare Searsy v. Commercial Trading Corp., 560 S.W.2d 637, 640 (Tex. 1977) andThOMAS LeE HAZEN, TrEatISE ON THE LAW OF SECURITIES REGULATION § 1.6[2] (2014), available at Westlaw (stating the Test via four factors) with SEC v. Life Partners, Inc., 87 F.3d 536, 540 (D.C. Cir. 1996) (offering the identical elements-investment in a common enterprise with the expectation of profits derived from the efforts of others--in three factors).

187. Int'l Bhd. of Teamsters v. Daniel, 439 U.S. 551, 552 (1979) (finding a compulsory but noncontributory pension plan to not constitute a security under either the 1933 Act or the 1934 Act); see also Employee Benefit Plans, Exchange Act Release, No. 
sought unsuccessfully to access a pension plan that (unbeknownst to him) had been vitiated years earlier by a layoff from work; upon learning the disappointing news at retirement, he invoked the securities laws as a means of redress. ${ }^{188}$

The lower courts rewarded Daniel's creativity, but the Supreme Court ultimately ruled for his employer, finding that the employer's pension contributions on Daniel's behalf did not constitute the "investment of money" required by the first Howey element. ${ }^{189}$ While the Supreme Court decision noted an intervening act of Congress (namely, ERISA ${ }^{190}$ ), the majority opinion is most often cited for relaying a concrete standard that asks whether the value parted with by the investor equates to a "tangible and definable consideration."

Taking the cue from this broad standard, subsequent courts have far more often than not located sufficient Investor contribution in the fact pattern. Moreover, Daniel's analysis of "investment of cash" gained repute and grew to lead courts to conclude that it was "well established that cash is not the only form of contribution or investment that will create an investment contract." 192 And thus some less than intuitive "money investments" have been found for purposes of the Howey Test, including promissory notes, ${ }^{193}$ bartered-for goods and services, ${ }^{194}$ and even an employee's promise to work. ${ }^{195}$ Moreover, in the presence of outright sham or fraud, some courts have largely ignored legal distinctions and focused solely on whether "the investor must commit his assets to the enterprise in such a manner as to subject himself to

33, 6188, 1980 WL 29482, at *2 (Feb. 1, 1980). The SEC later clarified that it would deem voluntary pension plans securities, even in the presence of express Congressional intent to regulate pension plans through the 1974 adoption of the Employee Retirement Income Security Act. Id.at*9.

188. See generally Daniel, 439 U.S. at 553-56.

189. Id. at 559-61.

190. Employee Retirement Income Security Act of 1974, Pub. L. 93-406, 88 Stat. 829 (codified as amended at 29 U.S.C. $\S \S 1001-1461$ (2012)).

191. Daniel, 439 U.S. at 560.

192. Uselton v. Commercial Lovelace Motor Freight, Inc., 940 F.2d 564, 574 (10th Cir. 1991).

193. Hector v. Wiens, 533 F.2d 429, 432-33 (9th Cir. 1976).

194. Daniel, 439 U.S. at 560 n.12. But see United States v. Jones, 450 F.2d 523, 525 (5th Cir. 1971) (finding airline ticket vouchers not to be securities for purposes the prohibition against carriage of forged instruments set out in 18 U.S.C. $\S 2311$, even where such provision-which largely echoed the 1933 Act and 1934 definitional sectionsspecifically included "evidence of indebtedness").

195. Yoder v. Orthomolecular Nutrition Inst., Inc., 751 F.2d 555, 560 (2d Cir. 1985) (finding investment where the plaintiff "commit[ted] herself to employment" in return for the promise of employer's stock). 
financial loss." ${ }^{" 196}$ More globally, the Supreme Court, when evaluating Investor contributions and returns, has actively supported the timehonored expansionist reading of the statutory definition, refusing to parse granular distinctions between present/future consideration ${ }^{197}$ and fixed/variable returns on investment. ${ }^{198}$

Further, even when subdivided into "investment" and "money," the element remains easily established, as noted by scholars ${ }^{199}$ and judges. ${ }^{200}$ It appears that any nuanced reading of the first element is subsumed in subsequent Test factors. For this and other reasons, these other Howey elements provide a more traversed battleground.

\section{2. ". . in a common enterprise. . ."}

"Commonality" is an occasionally thorny determination for courts and regulators alike. The Howey case indirectly provided an initial description of the element through its fact pattern, which summarized an arrangement whereby numerous investors contribute to a promoter's plan, with the expectation of a pro rata distribution of any resulting profits. ${ }^{201}$ But the Howey case did not actually define this "common enterprise" element. ${ }^{202}$ Accordingly, subsequent federal courts searched

196. SEC v. Pinckney, 923 F. Supp. 76, 80 (E.D.N.C. 1996) (quoting Hector v. Wiens, 533 F.2d 429, 432 (9th Cir. 1976)); see also Gary Plastic Packaging Corp. v. Merrill Lynch, Pierce, Fenner \& Smith, Inc., 756 F.2d 230, 239 (2d Cir. 1985) (citing Marine Bank v. Weaver, 455 U.S. 551 (1982)).

197. See Holloway v. Peat, Marwick, Mitchell \& Co., 879 F.2d 772, 783 (10th Cir. 1989) (finding passbook savings certificates to constitute a security), remanded by 494 U.S. 1014 (1990) (ordering consideration of investment contract as a "note" in light of intervening decision in Reves v. Ernst \& Young, 494 U.S. 56 (1990)).

198. See SEC v. Edwards, 540 U.S. 389, 391, 397 (2004) (finding that a payphone sale-and-leaseback agreement satisfied the Howey test, and that a fixed rate of return-as opposed to a variable rate-did not negate the presence of a security); but see Fishoff $\mathrm{v}$. Coty Inc., No. 09 Civ. 628 (SAS), 2009 WL 1585769, at *1, *6 (S.D.N.Y. June 8, 2009) (finding a corporation's long term incentive plan, which provided performance incentives for some employees, to not constitute a security).

199. See Thomas Lee Hazen, Securities Regulation: Cases and Materials 14041 (7th ed. 2006) ("The 'of money' element is easily disposed of, since it is clear that 'money' in this context is simply shorthand for 'something of value."').

200. See supra notes 195-97.

201. See, e.g., SEC v. Infinity Grp. Co., 993 F.Supp. 321, 322 n.1 (E.D. Pa. 1998) (defining horizontal commonality while noting that only the Fifth, Eighth, Ninth and Tenth Circuits require it).

202. Jonathan E. Shook, Note, The Common Enterprise Test: Getting Horizontal or Going Verticle in Wals v. Fox Hills Development Corp., 30 TULSA L.J. 727, 730 (1995) (citing Shawn Hill Crook, Comment, What is a Common Enterprise? Horizontal and Vertical Commonality in an Investment Contract Analysis, 19 CUMB. L. REV. 323, 325 (1989)) ("Unfortunately, because neither the Court in Howey nor any subsequent Supreme Court decision has defined the 'common enterprise' prong of the Howey test, the federal 
for numerous investors pursuing common dreams as the means of satisfying the second element of the Howey Test, coined (in hindsight) "Horizontal Commonality."203

Such a construction, among other things, potentially leaves the solitary investor without recourse under federal securities law, prompting a considerable amount of post-Howey courts to view commonality in a different fashion (i.e., as referring to the vertical relationship between Promoter and Investor). ${ }^{204}$ Thus was cemented the notion of vertical commonality, allowing a sole investor to bring a claim passing element two of the test. ${ }^{205}$ This interpretation of Howey permitted the SEC to twice successfully charge a notorious Ponzischeme artist of the early 1970 s. $^{206}$

In turn, vertical commonality was juridically divided into strict and broad varieties, enthusiastically embraced by litigants and opportunistically utilized by the SEC. "Strict" vertical commonality requires that the economic fates of the Promoter and Investor be tied and that their fortunes rise and fall together; ${ }^{207}$ the focus rests upon a closely-aligned "one-to-one relationship between the investor and investment manager." 208 Conversely, "broad" vertical commonality requires only that the "efforts" of Promoter and Investor be "linked."209

courts have been left to disagree. . .") (emphasis added).

203. See, e.g., Infinity Grp. Co., 993 F. Supp.at 322(finding horizontal commonality "ampl[y]" satisfied" where over 10,000 investors contributed over $\$ 26$ million to a purported stick investment trust); see also Steinhardt Grp., Inc. v. Citicorp, 126 F.3d 144, 151 (3d Cir. 1997) (stating that horizontal commonality "requires a pooling of investors' contributions and distributions of profits and losses on a pro-rata basis among investors.") (quoting Maura K. Monaghan, An Uncommon State of Confusion: The Common Enterprise Element of Investment Contract Analysis, 63 FORDHAM L. REV. 2135, 2152-53 (1995)).

204. See generally, Miriam R. Albert, The Howey Test Turns 64: Are the Courts Grading This Test on a Curve?, 2 WM. \& MARY BUS. L.J. 1, 17-19 (2011); see also SEC v. Glenn W. Turner Enters., Inc., 474 F.2d 476, 482 (9th Cir. 1973) (concluding that a multimarketing scheme, when viewed as an investment by an individual availing himself of a recruitment scheme designed and promoted by others, constituted an investment contract). The simplified approach to commonality announced by Turner has been followed by subsequent federal courts. See, e.g., Webster v. Omnitrition Int'l, Inc., 79 F.3d 776 (9th Cir. 1996); SEC v. Novus Techs., LLC, No. 2:07-CV-235-TC, 2010 WL 4180550, at *8 (D. Utah Oct. 20, 2010) ("Indeed, investors were told that [the defendant company] could pay such a high interest rate because it 'earns more than it pays out.").

205. See SEC v. Koscot Interplanetary, Inc., 497 F.2d 473 (5th Cir. 1974); see also Marini v. Adamo, 812 F. Supp. 2d 243, 255 (E.D.N.Y. 2011) (noting that vertical commonality does not focus on a "pooling of funds").

206. See generally Koscot, 497 F.2d at 477; see alsoMarini, 812 F. Supp. $2 \mathrm{~d}$ at 255.

207. Marini, 812 F. Supp. 2 d at 256.

208. Id. (quoting Kaplan v. Shapiro, 655 F. Supp. 336, 341 (S.D.N.Y. 1987)).

209. Marini, 812 F. Supp. 2d at 255-56. But see Revak v. SEC Realty Corp., 18 F.3d 
The Supreme Court has not determined which, if any, of the versions is universally required.

The result is a universal understanding that there exists a number of options by which to satisfy Howey's commonality requirement, ${ }^{210}$ and a sole consumer/Investor need not be rigidly excluded from invoking the Securities Acts.

\section{3. ". . . with the expectation of profits ..."}

The third element of the test is largely synonymous with the marketing of the financial arrangement. In Howey, the element was satisfied by the incontrovertible evidence that the purchasers of units of a partitioned orange grove were promised a slice of the profits. ${ }^{211}$ Specifically, the Supreme Court found that the Promoter's statements of a higher than average return on investment significantly influenced the Investor's decision. ${ }^{212}$

Emblematic of the judiciary's eagerness to find the present of a profit expectation is Teague v. Bakker, ${ }^{213}$ a famed Fourth Circuit decision declaring a resort time share (titled "Life Time Partnership") to be a security:

We conclude, then, that the promotional materials used to market the LTPs can be seen as emphasizing the profit potential of the LTPs. The materials not only speak of the LTPs as "investment[s]," but also offer specific calculations of the true value of the LTPs as compared to their purchase price. The materials also allow the reader to infer that the value of the LTPs was enhanced by virtue of the commercial activities of the [Promoter] in catering to patrons paying full price. Moreover, it is clear... that this benefit arises from the managerial efforts of others. $^{214}$

In short, the "expectation of profits" element is often readily proven by the Promoter's wistful statements or advertising of successful

81 (2d Cir. 1994) (rejecting broad vertical commonality).

210. See, e.g., James D. Gordon III, Defining A Common Enterprise in Investment Contracts, 72 OHIO ST. L.J. 59, 68-69 (2011) (noting that the Fifth and Eleventh Circuits utilize broad commonality, and that three other Circuits have not expressly ruled on it); see also id. at 69 ("The Tenth Circuit has rejected a requirement of horizontal commonality in favor of an 'economic reality' approach."). Thus, on the whole, broad vertical commonality is a pleading possibility in half of the federal circuits.See id.at 69-70.

211. SEC v. W.J. Howey Co., 328 U.S. 293, 294-96, 300 (1946).

212. Id. at 296,300 ("[The investors] are attracted by the expectation of substantial profits. It was represented, for example, that profits during the 1943-44 season amounted to $20 \%$ and that even greater profits might be expected during the 1944-45 season ....").

213. 35 F.3d 978, 987 (4th Cir. 1994).

214. Id. at 989 . 
commercial activities.

\section{4. “. . derived solely from the efforts of others . . ."}

The most problematic of Howey's elements may be the final consideration, which speaks to the gist of the test: whether the Investor is truly passive, or he expends enough effort to assume the role of Promoter himself. ${ }^{215}$

In this analysis, the significant efforts may be supplied by "others" (i.e., third parties). Howey had arguably emphasized the "sole" efforts of the Promoter. ${ }^{216}$ But subsequent cases explored varying verbiage to loosen this standard, and thus a finding of a security will stand despite the defense that the Promoter did not supply the lone efforts. ${ }^{217}$ Also, in evaluating whether the requisite "efforts" come from others, the stated intentions of the Promoter (as opposed to his actions) suffice. ${ }^{218}$

Perhaps the most insightful court decision (as well as one of the most noted SEC defeats) in this line of rulings came from the Life Partners case, ${ }^{219}$ in which controversial "viatical settlements"220 were deemed beyond the reach of the Acts by the D.C. Court of Appeals. In finding the fractionalized interests in the life insurance proceeds of dying individuals outside the definition of security, the court noted, among other things, that the significant efforts were (1) arguably contributed by a third party (i.e., the insured person) ${ }^{221}$ and (2) when undeniably contributed by the Promoter, merely ministerial in nature. ${ }^{222}$

After Life Partners, there ensued a line of cases debating whether those securitizing the death benefits of the dying contributed significant

215. See generally Albert, supra note 204, at 12.

216. See generally SEC v. W.J. Howey Co,, 382 U.S. 293, 301 (1946).

217. See, e.g., SEC v. Glenn W. Turner Enters., Inc., 474 F.2d 476, 482 (9th Cir. 1973) (requiring only that "the efforts made by those other than the investor are the undeniably significant ones, those essential managerial efforts which affect the failure or success of the enterprise").

218. SEC v. The Infinity Grp. Co., 993 F.Supp. 321, 322 (E.D. Pa. 1998) (citing SEC v. United Benefit Life Ins. Co., 387 U.S. 202, 211 (1967)).

219. SEC v. Life Partners, Inc., 87 F.3d 536 (D.C. Cir. 1996).

220. SEC, Viatical Settlements (last visited Sept. 22, 2014), http://www.sec.gov/answers/viaticalsettle.htm ("A viatical settlement allows you to invest in another person's life insurance policy. With a viatical settlement, you purchase the policy (or part of it) at a price that is less than the death benefit of the policy. When the seller dies, you collect the death benefit.").

221. Life Partners, Inc., 87 F.3d at 548 ("In this case it is the length of the insured's life that is of overwhelming importance to the value of the viatical settlements marketed by [the defendant].").

222. Id. at 546 (noting that the defendant "provide[d] no post-purchase services"). 
efforts under the law. The significance of Life Partners was ultimately attenuated on the second ground (i.e., that such efforts were much more important to the enterprise than originally construed). For example, an Ohio district court found in 2005 that the defendant's choice of insurance agent was crucial to the success of the investment scheme; ${ }^{223}$ earlier this year, to the same end, the Texas high court found a security in a case against Life Partners itself. ${ }^{224}$ With intentions counting as much as actions in a formula that eschews a zero-sum game, the result is a fourth element that (1) discounts Investor efforts in favor of Promoter expertise, and (2) can readily be met with ample proof of the prior three elements. ${ }^{225}$

Overall, despite some hiccups, Howey transformed the 1933 Act and 1934 Act into dynamic statutes that would forever value the dual promises of section 5 (i.e., registration and prospectus delivery). ${ }^{226}$ Moreover, the federal bench has continued to uphold Howey's promise of protection for Investors in securities traditional or otherwise; such continued protection is laudable for, among other reasons, the vulnerability and political nature of agency-made law in general. ${ }^{227}$

\section{Raising the Drawbridge: Limitations on the Expansive Definition}

At varied times, courts have expressly exempted categories of putative "investments" from the SEC's reach. Cases citing Howey have carved out distinctions for investments met with tangible goods for consumption. ${ }^{228}$ Additionally, courts have actively intervened to halt expansion of the definition of the term "security" in the presence of an alternative regulatory scheme. For example, certificates of deposit-in

223. Wuliger v. Mann, No. 3:03 CV 1531, 2005 WL 1566751, at *4 (N.D. Ohio July 1, 2005) (quoting Life Partners, Inc., 87 F.3d at 551) (Wald, J., dissenting) (noting that "form should not be elevated over substance and economic reality").

224. Arnold v. Life Partners, Inc., 416 S.W.3d 577, $592-93$ (Tex. App. 2014).

225. See, e.g., United States v. Leonard, 529 F.3d 83, 88 (2d Cir. 2008) ("Following the Ninth Circuit's lead, we have held that the word 'solely' should not be construed as a literal limitation; rather, we "consider whether, under all the circumstances, the scheme was being promoted primarily as an investment or as a means whereby participants could pool their own activities, their money and the promoter's contribution in a meaningful way."') (internal citations omitted).

226. HAZEN, supra note 105, at 22-27.

227. William F. FoX, Understanding AdMINISTRATIVE LAW 54-57 (6th ed. 2012) (noting that the federal agencies' "administrator[s are] totally subject to Presidential control").

228. United Hous. Found., Inc. v. Forman, 421 U.S. 837, 851, 858 (1975) (finding "shares" of a cooperative apartment to not constitute a security because of, inter alia, their correspondence to a tangible living space). 
plain vanilla form-were exempted from SEC reach in the Marine Bank case of $1982 .{ }^{229}$ Likewise, commodity contracts are not normally found to be securities. ${ }^{230}$ And gambling ventures-which often grow money on efforts other than those of the investor-are characteristically left to State lottery laws. ${ }^{231}$ Alternatively, the quest for expansive jurisdiction has been halted where the investors were presumed sophisticated, as in the Steinhardt case of $1997 .{ }^{232}$

Thus, in 2014, the common denominators of cases applying Howey in expansive fashion appear to be (1) the presence of a manifest intention of an expert to assist the truly passive, unsophisticated investor who (2) is otherwise without recourse under the law. ${ }^{233}$ As any law student studying securities regulation is told, SEC over-reaching in defining securities is tempered by the modest remedy sought (i.e., registration with the Commission). Accordingly, armed with a broad definition, incalculable judicial support, and a mandate from the investing public, the SEC has used section 5 of the 1933 Act to exercise jurisdiction over arrangements far removed from those securities traded on stock exchanges, ${ }^{234}$ and to counter faddish investment frenzies

229. Marine Bank v. Weaver, 455 U.S. 551, 556, 559 (1982) (stating that Congress, in adopting the 1933 Act, did not "intend to provide a broad federal remedy for all fraud"). 1986).

230. See, e.g., Point Landing v. Omni Capital Int'l, Ltd., 795 F.2d 415, 422 (5th Cir.

231. See, e.g., Commonwealth v. Allen, 404 S.W.2d 464 (Ky. Ct. App. 1966);State v. ITM, Inc., 275 N.Y.S.2d 303 (Sup. Ct. N.Y. Cty. 1966).But see SEC v. SG Ltd., 265 F.3d 42, 44 (1st Cir. 2001) (denying a motion to dismiss an SEC Complaint alleging an online gaming venture to be a security). The case attracted much attention for the Commission's foray into the virtual gaming world, and included language buttressing the SEC's expansionist vision:

As long as the three-pronged Howey test is satisfied, the instrument must be classified as an investment contract. Once that has occurred, "it is immaterial whether the enterprise is speculative or non-speculative or whether there is a sale of property with or without intrinsic value." It is equally immaterial whether the promoter depicts the enterprise as a serious commercial venture or dubs it a game.

Id. at 48 (quoting SEC v. W.J. Howey Co., 382 U.S. 293, 301 (1946)).

232. Steinhardt Grp. Inc. v. Citicorp, 126 F.3d 144, 145, 151 (3d Cir. 1997) (finding a "highly structured securitization transaction" involving non-performing assets to fail the "efforts of others" element of the Howey test).

233. See generally Howey, 328 U.S. 293.

234. See Hector v. Wiens, 533 F.2d 429, 432-33 (9th Cir. 1976); United States v. Jones, 450 F.2d 523, 524 (5th Cir. 1971); Yoder v. Orthomolecular Nutrition Inst., Inc., 751 F.2d 555, 560 (2d Cir. 1984); see Bailey v. J.W.K. Props., Inc., 904 F.2d 918, 923 (4th Cir. 1990); Newmyer v Philatelic Leasing Ltd., 888 F.2d 385, 387 (6th Cir. 1989); SEC v. SG Ltd., 265 F.3d 42, 44 (1st Cir. 2001); Long v. Shultz Cattle Co., Inc., 881 F.2d 129, 130 (5th Cir. 1989); Marini v. Adamo, 812 F. Supp. 2d 243, 248 (E.D.N.Y. 2011); seeSEC. REG. \& L. REP., infra note 291; Bamert v. Pulte Home Corp., 445 F. App'x 256, 258-59 (11th Cir. 2011); Wolf v. Banco Nacional De Mex., 549 F. Supp. 841, 853 (N.D. Cal. 1982); Warfield 
centering on, among others, farm cooperative notes, ${ }^{235}$ condominiums, ${ }^{236}$ and collateralized debt obligations (including those of the synthetic genre) ${ }^{237}$ Even when a jurisdiction has seemingly closed the door on SEC jurisdiction, facts often surface permitting the case to proceed. ${ }^{238}$

The SEC has exhibited this expansive spirit (and historical bravado) where Bitcoins pay for the purchase of corporate shares; ${ }^{239}$ it is high time to take the application one step further.

\section{Application of the Howey Test to Bitcoin Exchange Sites}

It is axiomatic that the SEC has successfully brought unprecedented action against new fashions of investments-indeed, some might argue that the Howey Test can be used to reach any conceivably passive investor arrangement. The Howey progeny (now exceeding 1400 formal case citations ${ }^{240}$ ) employs various means of specific analysis, several of which are possible mechanisms of asserting SEC jurisdiction over Bitcoins.

v. Alaniz, 569 F.3d 1015, 1018 (9th Cir. 2009); Sheets v. Dziabis, 738 F. Supp. 307, 312 (N.D. Ind. 1990).

235. See Great Rivers Coop. of Se. Iowa v. Farmland Indus., Inc., 198 F.3d 685, 699 (8th Cir. 1999).

236. See SEC, Guidelines as to the Applicability of the Federal Securities Laws to Offers and Sales of Condominiums or Units in a Real Estate Development, Securities Act of 1933 Release No. 33-5347, 1973 WL 158443 at *2 (Jan. 4, 1973) ("The Howey case involved the sale and operation of orange groves. The reasoning, however, is applicable to condominiums.").

237. See Complaint I 13, SEC v. Goldman Sachs \& Co., 790 F. Supp. $2 d 147$ $\begin{array}{llllll}\text { (S.D.N.Y 2010) (No. } 10 & \text { Civ. } 3229 & \text { (BSJ)(MHD)), available }\end{array}$ atwww.sec.gov/litigation/litreleases/2010/lr21489.htm. Perhaps surprisingly, the question of whether the SEC possessed jurisdiction over a synthetic investment-i.e., one that references a portfolio of securities rather than owns the securities-was readily resolved in the Commission's favor.See SEC v. Goldman Sachs \& Co., 790 F. Supp. 2d. 147, 166 (S.D.N.Y. 2010).

238. See, e.g., Koch v. Hankins, 928 F.2d 1471, 1475-78 (9th Cir. 1991) (finding a general partnership, normally exempt from securities laws, to be a security where one general partner possessed a unique expertise upon which the investors relied); United States v. Leonard, 529 F.3d 83, 91 (2d Cir. 2008) (finding a limited liability company to constitute a security despite New York's LLC shield statute);SEC v. Aqua-Sonics Products Corp., 687 F.2d 577,585 (2d Cir. 1982) (finding a franchise agreement to be a security where the franchisor retained significant commission rights in a dental equipment sales arrangement).

239. See supra notes $93-97$ and accompanying text.

240. Westlaw Keycite search for authorities cases citing Howey. Westlaw, https://a.next.westlaw.com/ (last visited Aug. 4, 2014). 


\section{Under a Strict Howey Analysis}

Applying the first element of the Howey Test, it is readily apparent that customers utilizing Bitcoin Exchange Sites invest money (in cash or credit card form). Specifically, customers utilizing Bitcoin exchanges are universally informed of the percentage price of the process, ${ }^{241}$ further, the promised return is always financial (i.e., listed in Euros or U.S. dollars). ${ }^{242}$ Frequently, the practicalities dictate the creation of an account and the transfer of money thereto. The instructions are as straightforward as they are bold. ${ }^{243}$ In short, a "definable consideration" as explained by Danie $^{244}$ is not only sought but often a prerequisite to any transactional progress continuing. ${ }^{245}$ The application of the first of Howey's elements to Bitcoin Exchange Sites is thus non-controversial.

Concerning the second element of the Howey Test (i.e., a common enterprise), Investors evidence-at the very least-broad vertical commonality with their Promoters. Without people converting cash into Bitcoin (or vice versa), the Sites have no business model. This totality of enterprise approach often suffices to establish the linked efforts delineated by cases such as Turner ${ }^{246}$ and Koscot. ${ }^{247}$

One could argue that strict vertical commonality cannot be established by the SEC with regard to most Sites. The leading case for this restrictive approach is Brodt v. Bache, ${ }^{248}$ a suit by a customer against the broker-dealer that employed an allegedly dishonest stockbroker. ${ }^{249}$ In finding for the broker-dealer, the court noted that the failure of the entity would not necessarily mean that the customer would "suffer serious losses" because such accounts are insured; the inability to establish that both Promoter broker-dealer and Investor customer would rise and fall together was thus fatal in a strict vertical jurisdiction. $^{250}$

241. See supra notes $80-83$ and accompanying text.

242. See supra notes $77--78,80--83$ and accompanying text.

243. See supra notes $77--78,80--83$ and accompanying text.

244. See Int'l Bhd. of Teamsters, Chauffeurs, Warehousemen and Helpers of Am. v. Daniel, 439 U.S. 551, 560 (1979). Interestingly, while the purchase of Bitcoins by itself has not yet been held to constitute the purchase of a security, Bitcoin itself has been equated with cash for purposes of the first element of the Howey analysis. SEC v. Shavers, No. 4:13CV-416, 2013 WL 4028182, at *2 (E.D. Tex. Aug. 6, 2013) ("It is clear that Bitcoin can be used as money.").

245. See supra notes 77-78, 81-83 and accompanying text.

246. SEC v. Glenn W. Turner Enters., Inc., 474 F.2d 476 (9th Cir. 1973).

247. SEC v. Koscot Interplanetary, Inc., 497 F.2d 473 (5th Cir. 1974).

248. 592 F.2d 459 (9th Cir. 1978).

249. Id. at 462 .

250. Id. at 461 . 
But the fates of Bitcoin Exchange Sites are much more linked to their customers. When Mt. Gox was pilfered and bankrupted, its customers suffered. ${ }^{251}$ Likewise, no regulator stands ready to make whole those chancing their investments with Bitcoin exchanges, thus making the independent relationship touted in Brodt v. Bache $e^{252}$ a highly unlikely possibility at this time.

Regarding the third element of the test (i.e., expectation of profits), Investors undeniably answer a call for higher return. The language of Bitcoin Exchange Sites consistently infers (if not states) that Bitcoins are lucrative investments through a combination of charts, graphs, and/or historical prices. ${ }^{253}$ Further, these Sites benefit from the pervasive publicity for Bitcoin that floods the Internet. ${ }^{254}$ In sum, visitors to Bitcoin Sites believe that their virtual wallets shall be "enhanced by virtue of the commercial activities of the [Promoter]."255

Addressing the fourth and final element (i.e., efforts of others), Investors expend truly minimal efforts-namely, converting currencies at the original or other Site as prices rise. While a Site serving solely as a portal to the world of Bitcoin might be able to assert its lack of managerial efforts, significant efforts are being offered by certain exchanges. Some Sites offer to set a virtual wallet for visitors; others agree to act as repository for purchased Bitcoins. ${ }^{256}$ In such arrangements, significantly enabling actions are expended by the Promoter, bringing the arrangement within the court's interpretation of requisite "managerial efforts."257

Thus, supple precedent exists for the SEC to confidently proceed with the demand for registration by some Bitcoin exchange Sites. Such action is justified where Sites are requesting money while promising high returns for passive, uninformed Investors. Such regulatory result is naturally expected, as the landmark Howey decision sought (and consistently continues to seek) the regulation of those entities

251. See Thompson, supra note 62.

252. 595 F.2d 459.

253. See, e.g., BITSTAMP: FAQ, supra note 78.

254. See Leger, supra note 63 (taking note of the publicity-seeking Bitcoin Foundation); Complete List of Bitcoin Exchanges, supra note 61 (providing the link to PlanetBitcoin.com).

255. See Teague v. Bakker, 35 F.3d 978, 989 (4th Cir. 1994).

256. See supra notes 83 and accompanying text.

257. See, e.g., SEC v. Glenn W. Turner Enters., Inc., 474 F.2d 476, 482 (9th Cir. 1973) (defining the required efforts as "those essential managerial efforts which affect the failure or success of the enterprise"); United Hous. Found., Inc. v. Forman, 421 U.S. 837, 852 (1975) (defining as the "touch[]stone" a premise of a "reasonable expectation of profits to be derived from the entrepreneurial or managerial efforts of others"). 
evidencing "all the elements of a profit-seeking business venture."258

If the concern be that some courts may stringently apply each variety of the Howey Test elements, there nonetheless exists a more flexible (and judicially created) approach.

\section{Under a Risk of Loss Analysis}

A slightly distinct risk of loss analysis, followed at times by the Second and Ninth Circuits, perhaps poses fewer obstacles for a Commission action. This variation on the Howey analysis emphasizes the practical ramifications of the financial arrangement, thus discounting such factors as proof of pro rata distribution of profits in favor of the presence of an undeniable group of passive Investors.

The landmark case for this alternative analysis is Silver Hills Country Club v. Sobieski, ${ }^{259}$ in which a country club membership was deemed a security because of the Promoter's planned use of the members' fees. ${ }^{260}$ The Silver Hills court noted that the membership fees at issue were crucial to the initial development of the business. ${ }^{261}$ Noteworthy is that Bitcoin Exchange Sites are often discussed in the press as start-up enterprises, ${ }^{262}$ thus making them a good fit for Promoter under a risk of loss application of the Securities Acts.

A subsequent case more expressly advancing this totality view is United States v. Carman, involving insured student loan packages sold by a trade school. ${ }^{263}$ The Carman court noted that the sale agreement included both a repurchase clause and the guarantee that the trade school would cover any refund liability (i.e., damage to the investment occasioned by students' failure to stick to the original payment schedule). ${ }^{264}$ In Brodt, the court summed up the Carman court's satisfaction of the most troublesome Howey factor: "[t]hus, a substantial risk of loss for the investor on the school's failure was sufficient to create a common enterprise, even though there was no common enterprise between the school and the credit union." ${ }^{265}$ If in fact the lack of horizontal or strict vertical commonality is troublesome to any

258. SEC v. W. J. Howey Co., 328 U.S. 293, 300 (1946).

259. 361 P.2d 906 (Cal. 1961).

260. Id. at 907.

261. Id. at 908 .

262. See, e.g., Pete Rizzo, Expresscoin Launches to Become Coinbase, COINDESK.COM (June 11, 2014), www.coindesk.com/expresscoin-launches-becomecoinbase-unbanked (discussing the 2014 conversion of the young company).

263. 577 F.2d 556, 559 (9th Cir. 1978).

264. Id. at 560,564 .

265. Brodt v. Bache \& Co., 595 F.2d 459, 461 (9th Cir. 1978). 
potential SEC case, this language - which substitutes the degree of potential investor hardship for considerations of similarity of Promoter/Investor plight—might be crucial.

Apart from doctrines and their monikers, in recent years, this focus on Promoter expertise has expanded the definition of security when the arrangement fueled criminal activity-even in the face of the protections of New York's Limited Liability Company Act. Specifically, in the 2008 case of United States v. Leonard, the Second Circuit affirmed all convictions flowing from facially protected investments in an independent film project, stating that "courts can (and should) look beyond the formal terms of a relationship to the reality of the parties' positions to evaluate whether 'the reasonable expectation was one of significant investor control."'266

Indeed, many court holdings subordinate tests and their elements to the protective mission of the securities laws. For example, in Reves $v$. Ernst \& Young, the high bench noted that a decision for the defendant would place the subject financial arrangement completely outside the reach of the law; $;{ }^{267}$ more pointedly, in Aqua-Sonic, the court found a security even in the face of a written franchise agreement, reasoning that "it would circumvent the purposes of the securities laws to exonerate defendants who had the guile to insert the requirement that the buyer contribute a modicum of effort." 268

Once identifying a security, the SEC would then be permitted to charge famed SEC Rule 10b-5 (itself quite an elastic provision) to cover any Site misstatements. ${ }^{269}$ Finally, the fact that Bitcoin exchanges are

266. 529 F.3d 83, 85 (2d Cir. 2008) (quoting SEC v. Aqua-Sonic Prods. Corp., 687 F.2d 577, 585 (2d Cir. 1982) (finding a security in a franchise agreement where the franchisor retained too much control in the form of commissions).

267. 494 U.S. 56, 63 (1990) (stands as authority for use of the Second Circuit's "family resemblance test" to determine whether the Acts reach an investment as a note). The present Article does not posit that Bitcoin can be equated with a statutory note; consequentially, the Article also does not evaluate an investment in Bitcoin under the Acts' definitions of "evidence of indebtedness." See Proctor \& Gamble Co. v. Bankers Trust Co., 925 F. Supp. 1270, 1280 (S.D. Ohio 1996) (citations omitted) ("The test whether an instrument is within the category of 'evidence of indebtedness' is essentially the same as whether an instrument is a note").

268. Aqua-Sonic, 687 F.2d at 584.

269. Promulgated pursuant to 1934 Act $\S 10$ b, 15 U.S.C. $\S 78(j)$ (b) (2012). Rule 10b-5 provides in relevant part as follows:

It shall be unlawful for any person, directly or indirectly, by the use of any means or instrumentality of interstate commerce, or of the mails or of any facility of any national securities exchange, ...

(b) To make any untrue statement of a material fact or to omit to state a material fact necessary in order to make the statements made, in the light of the circumstances 
foreign entities ${ }^{270}$ is a nullity, as the Commission has enjoyed a great many successes in exporting American securities law ${ }^{271}$ to foreign companies victimizing U.S. Investors. ${ }^{272}$

\section{As a Response to These Troubled Times...}

Aside from potentially technical application of elements and precedents, there exists a cogent rationale for the expansion of SEC efforts to rein in Bitcoin. Since 1946, the Howey test has often emphasized public perception of the financial arrangement in issue, and Bitcoin is increasingly seen as an investment. ${ }^{273}$ As such, it poses the traditional dangers to the uninformed. The test's chief progenitor, the SEC, for the past decade has been actively pursuing all schemes that tarnish the American market.

For example, the $2001 S G L t d .^{274}$ case exemplifies the willingness of the Commission to foreclose online gaming as a sub rosa investment scheme. ${ }^{275}$ In that case, the First Circuit rejected the district court's "dichotomy between business dealings" and virtual games. ${ }^{276}$ The decision not only sustained the Commission's aggressive Complaint (depicting "virtual shares" purchased by 800 American domiciliaries as securities) but did so in language hauntingly familiar of the threat posed by Bitcoin:

In defining the scope of the market that it wished to regulate, Congress painted with a broad brush. It recognized the virtually limitless scope

under which they were made, not misleading.

17 C.F.R. $\$ 240.10 b-5(b)$ (2014).

270. See Why Financial Services Firms Should Prepare For Bitcoin, supra note 90 ("There exist several Bitcoin "exchanges," the majority of which are in Asia and Europe.").

271. Congress and the federal judiciary have, respectively, provided for and consistently upheld the right of the Commission to investigate and discipline foreign entities engaging in securities transactions with American citizens. See, e.g., Section 22(c) of the 1933 Act, 15 U.S.C. $\$ 77 \mathrm{v}(\mathrm{c})(2)$ (granting SEC authority over violations of section 77(q)(a) where the foreign conduct has a foreseeable substantial effect within the United States.); see also Section $30 \mathrm{~b}$ of the 1934 Act, 15 U.S.C. $\S 78 \mathrm{~b}(1)$ (clarifying SEC authority to promulgate rules reaching foreign conduct).

272. See, e.g., Robert Moore D/B/A The Kingdom of Enenkio Consents to a Permanent Injunction and Contempt Order,SEC NEWS DIGEST/ENFORCEMENT ProceEDINGS, (Oct. 27, 2000), http://www.sec.gov/news/digest/10-27.txt (detailing the Commission's action against a foreign, transient defendant for his sale of unregistered "Gold War Bonds" to American investors via the Internet).

273. See supra notes 13 (describing NASAA's alarm), 39 (describing the registered Winklevoss investment scheme).

274. SEC v. SG Ltd., 265 F.3d 42 (1st Cir. 2001).

275. Id. at 48 .

276. Id. 
of human ingenuity, especially in the creation of "countless and variable schemes devised by those who seek the use of the money of others on the promise of profits," and determined that the best way to achieve its goal of protecting investors was "to define the term 'security' in sufficiently broad and general terms so as to include within that definition the many types of instruments that in our commercial world fall within the ordinary concept of a security."277

While an online game soliciting $\$ 4.7$ million from Investors ${ }^{278}$ might be novel, the holding of the case was impressively steadfast: under American securities law, on the question of whether a security has been created, names matter little.

More recently, the SEC made clear that those laws would play a meaningful role in establishing accountability for the financial crisis, providing little room for any debate that a "synthetic CDO"279 is not a security. ${ }^{280}$ And thus, the Commission obtained one of its largest civil judgments against an investment banking concern ${ }^{281}$ and an impressive jury verdict against one of its traders, ${ }^{282}$ both actions premised on the novel theory that a "shadow" investment (i.e., a CDO with no actual holdings) animated by an insurance vehicle (i.e., a credit default swap) is a security. ${ }^{283}$

277. Id. (citations omitted).

278. Id. 17.

279. Unlike a plain CDO, which invests in tangible debts and loans, a "synthetic collateralised [sic] debt obligation is a derivative created from the securitization of a portfolio of credit default swaps. A synthetic CDO does not own actual fixed income assets such as bonds or loans. It gains exposure to the assets through the credit default swaps."Financial Glossary: Synthetic $C D O$,http://glossary.reuters.com/index.php?title=Synthetic_CDO (last visited Sept. 22, 2014).

280. Id.

281. See Jennifer O'Hare, Synthetic CDOs, Conflicts of Interest, and Securities Fraud, 48 U. RICH. L. REv. 667, 707-10 (2014) Professor O'Hare aptly sums up the respective positions of Goldman Sachs and the SEC leading up to the firm's landmark settlement of $\$ 550$ million for "mistake[nly]" touting a doomed CDO to a customer. Id. Notably, battle lines were drawn regarding whether the synthetic CDO even came within the securities laws, a point the SEC admirably advanced in its original Complaint. Id. See also Complaint If 13, SEC v. Goldman Sachs \& Co., 790 F. Supp. 2d 147 (S.D.N.Y 2010) (No. 10 Civ. 3229 (BSJ)(MHD)), available at www.sec.gov/litigation/litreleases/2010/lr21489.htm.

282. O'Hare, supra note 281, at 710. In 2013, former Goldman Sachs trader Fabrice "Fabulous Fab" Tourre was found liable for 6 counts of fraud by a Manhattan jury. Id.See alsoJoshua Brustein, True Believers Cheer the Fall of Bitcoin Exchange Mt. Gox, Bus. WK. (Feb. 25, 2014), http://www.businessweek.com/articles/2014-02-25/bitcoin-exchange-mtdot-gox-falls-true-believers-cheer.

283. Complaint ๆ 13, Goldman Sachs, 790 F. Supp. 2d 147. 
Thus, there are a number of means of effectuating SEC activism, and the combination of law, policy, and public sentiment augurs well for Commission efforts at this task. Such a new stance would, at the very least, implement rules governing communication by Bitcoin exchange sites while, at the most, reaffirm the Commission's roles as ultimate securities regulator. To the extent critics would parse the applications described herein, such counterarguments are easily met.

\section{E. Counter-Analyses}

In eighteen months, Bitcoin market value skyrocketed and plummeted close to $2000 \% .{ }^{284}$ While some might scoff at regulation of a promotion so fanciful as to be unbelievable, it was aptly noted by Judge Posner years ago that securities law must not yield to schemes simply because they are too good to be true. ${ }^{285}$

Separately, generic opposition to SEC activism regarding Bitcoin Exchange Sites could also point to the imbalance among the agency's stated objectives, to wit, capital formation and market regulation. As far back as 1980, informed critics charged the Commission with stifling innovation and hindering markets through a rush to "prosecute."286 But such ideology is rendered inapplicable by its own definitions. Bitcoin, as an innovation, seeks primarily to place commerce completely beyond regulatory reach; even a reputable critic such as Professor Karmel would be hard pressed to defend no regulation of such substantial business activity. ${ }^{287}$ Additionally, lacking shareholders, quotes, annual reports, dividends, and universality, Bitcoin lacks both a formal market and rivals, making increased market productivity via light regulation an illusion at best. ${ }^{288}$

Additionally, critics might (justifiably) note the Commission's crowded agenda, highlighting the extreme delay attending derivative reforms. Specifically, while the Dodd-Frank Act $^{289}$ expressly called for,

284. See supra notes 68-69 and accompanying text.

285. See SEC v. Lauer, 52 F.3d 667, 670 (7th Cir. 1995) ("It would be a considerable paradox if the worse the securities fraud, the less applicable the securities laws.").

286. See, e.g., Roberta S. Karmel, Regulation by Prosecution, The Securities AND EXChange COMmISSION Versus CORPORATE AMERICA 298-99 (1982). Presaging an array of future election year polemics, Professor Karmel, a former SEC Commissioner, wrote:"I believe there is a need today to change the direction of federal regulatory agencies generally, and the SEC in particular, so that regulation will work in favor of, rather than, as is often now the case, against capital formation and improved business productivity." Id.

287. See generally id.

288. Id.

289. Dodd-Frank Wall Street Reform and Consumer Protection Act, Pub. L. 111-203, 124 Stat. $1376(2010)$. 
among other things, mandatory clearing of securities an commodity based derivatives "through regulated central clearing organizations," the details of key, related definitions have been extended seemingly indefinitely. ${ }^{291}$ But the SEC has long boasted of its overwhelming lists of obligations, and is fully capable of effectively highlighting that list for purposes of budgetary and staffing increases.

Further buttressing the case for expanded SEC targeting of Bitcoin are the agency's past inclinations and related track record. The Commission's applications of the securities laws to unconventional arrangements are as whimsical as they are legion: a short list might amplify recent cases involving cattle embryos, ${ }^{292}$ postage stamps for mail on privately owned islands, ${ }^{293}$ online investment games, ${ }^{294}$ a livestock-feeding consulting agreement, ${ }^{295}$ rare coins, ${ }^{296}$ credit default swaps, ${ }^{297}$ condominium subletting agreements, ${ }^{298}$ deposits in a Mexican bank, ${ }^{299}$ charitable gifts, ${ }^{300}$ and even a "stallion syndication" contract. ${ }^{301}$ Juxtaposed with such a history of stretching Howey in the name of Investor protection, a short list of actions against the most dangerous of Sites seems only natural.

To be sure, more pointed criticism might highlight application of the last and arguably most critical Howey test elements. Bitcoin Investors, at times, are technologically savvy. In turn, a number of Site visitors no doubt have created their own wallets and otherwise independently researched the Bitcoin market. Such efforts could make classification of such consumers as "passive" belabored. ${ }^{302}$

290. See Summary of the Dodd-Frank Wall Street Reform and Consumer Protection Act, Enacted into Law on July 2I, 2010, Davis POLK CLIENT NEWSLETTER, July 2010 at 5263, available

http://www.davispolk.com/resources/all?nid=56797\&field_pb_publication_type_tid_l $1=589$ 8; see also id. at 44-46. Title VII of the Dodd-Frank Act also required the registration of dealers in subject derivatives, and that banks "pushout" subject "swaps" to their affiliates.Id.

291. See, e.g., SEC Exempts Security-Based Swaps From Coverage as 'Securities' Until 2017, 46 SEC. REG. \& L. REP. (BNA) No. 255 (Feb. 10, 2014).

292. Bailey v. J.W.K Props., Inc., 904 F.2d 918, 923 (4th Cir. 1990).

293. Newmyer v. Philatelic Leasing, Ltd., 888 F.2d 385, 387 (6th Cir. 1989).

294. SEC v. SG Ltd., 265 F.3d 42, 44 (1st Cir. 2001).

295. Long v. Shultz Cattle Co., Inc., 881 F.2d 129, 130 (5th Cir. 1989).

296. Marini v. Adamo, 812 F. Supp. 2d 243, 248 (E.D.N.Y. 2011).

297. See Swaps in [Fabrice] Tourre Case 'Based' on Securities, SEC. REG. \& L. REP. (BNA), July 22, 2013.

298. Bamert v. Pulte Home Corp., 445 F. App'x 256, 258-59 (11th Cir. 2011).

299. Wolf v. Banco Nacional De Mex., 549 F. Supp. 841, 853 (N.D. Cal. 1982).

300. Warfield v. Alaniz, 569 F.3d 1015, 1018 (9th Cir. 2009).

301. Sheets v. Dziabis, 738 F. Supp. 307, 312 (N.D. Ind. 1990).

302. See, e.g., SEC v. Life Partners, Inc., 87 F.3d 536 (refusing to find a security 
But the Koscot decision-in which Investors of the Ponzi scheme ranged from those simply selling retail cosmetics to those who actively participated in the recruitment aspects of the enterprise ${ }^{303}$ - has long clarified that a scheme is no less violative because some of its Investors provide meaningful efforts. ${ }^{304}$ Further, such a modicum of efforts defense ignores the capabilities of the Promoter, who possesses far more insight and skill regarding Bitcoin than does the first-time Investor. ${ }^{305}$ Interestingly, even the universal acceptance among federal regulators of Bitcoin as a new currency would lighten the Commission's load, as investments of money in currencies have themselves been found to satisfy the Howey test. ${ }^{306}$

In sum, the agency charged with protecting Investors is best poised for the inevitable clashes between Investor hopes and issuer shields, battles from which the Commission has never shied in the past. In this instance, popular commentary may be presciently informed, advocating recognition of the cryptocurrency but suggesting some level of regulation thereof. ${ }^{307}$

In the end, the most valid argument against forced registration traces back to perennial debates on SEC funding and resources. Thus, the true issue appears to be one of political will. Overall, forced registration of some Bitcoin Exchange Sites would weed out the false "exchanges" and hold the valid ones to a common standard.

\section{CONCLUSION: WEAPONS WITHIN REACH}

In the 1970s, a Ponzi scheme artist named Glenn Turner ${ }^{308}$ traveled from state to state peddling schemes ostensibly centering on wholesale sales of cosmetics and self-help audio tapes. ${ }^{309}$ His storied journey was cut short by two SEC actions in separate circuits finding securities fraud

where the putative Investors exerted only "ministerial" efforts).

303. SEC v. Koscot Interplanetary, Inc., 497 F.2d 473, 475 (5th Cir. 1974).

304. See generally id.

305. See United States v. Leonard, 529 F.3d 83, 88-91 (2d Cir. 2008).

306. See generally Complaint, SEC v. Boston Trading and Research, LLC, No. 1:10CV-11841, (D. Mass. Oct. 28, 2010), available at http://www.sec.gov/litigation/complaints/2010/comp21712.pdf (alleging a security in the agreement to invest contributions in forex (i.e., foreign currency) "trading venture").

307. See, e.g., Nathaniel Popper, Regulators See Value in Bitcoin, and Investors Hasten to Agree, N.Y. TIMES, Nov. 19, 2013, at B1, available at http://dealbook.nytimes.com/2013/11/18/regulators-see-value-in-bitcoin-and-investorshasten-to-agree/?_r=0.

308. See SEC v. G.W. Turner Enters., Inc., 474 F.2d 476 (9th Cir. 1973).

309. SEC v. Koscot Interplanetary, Inc., 497 F.2d 473, 475 n.4, 480 (5th Cir. 1974) (noting seventeen separate actions in ten federal districts against Turner-controlled entities). 
among his misdealings. ${ }^{310}$

In the 1990s, the SEC targeted complex, three-party, fractionalized life insurance assignments. After a notorious setback in the D.C. Circuit's Life Partners case, ${ }^{311}$ the SEC regrouped and successfully targeted viatical settlements and related "death bonds." 312

More recently, the SEC has policed public companies for discriminatory hiring practices and investments in illegal foreign regimes. ${ }^{313}$

It may be time again for the agency with the billion-dollar budget $^{314}$ to trot out its White Horse. On one level, Bitcoin represents some creative thinking in a global market increasingly dominated by a condensed list of major banks (and their audacious retail fees). ${ }^{315}$ But on a far more dangerous level, Bitcoin has created an inscrutable platform for fraud that is presently outpacing regulators and private attorneys alike. ${ }^{316}$ More active SEC regulation of Bitcoin is not only warranted but commensurate with existing case law and destined to instill

310. See Turner Enters., 474 F.2d 476; and Koscot, 497 F.2d 473.

311. See SEC v. Life Partners, Inc., 87 F.3d 536 (D.C. Cir. 1996).

312. See, e.g., SEC v. Tyler, No. Civ.A.3:02 CV 0282 P, 2002 WL 32538418, at *7-8 (N.D. Tex. Feb. 21, 2002) (granting a preliminary injunction against promoter of investments securities backed by viatical settlements based upon findings of misleading statements); SEC v. Mut. Benefits Corp., 408 F.3d 737, 741 (11th Cir. 2005) (finding the promoter of viatical policies to contribute the managerial efforts necessary to satisfy the Howey Test). Moreover, in 2014, the Texas high court declared viatical settlements to be securities for purposes of the Texas Securities Act. See Amold v. Life Partners, Inc., 416 S.W.3d 577, 592 (Tex. Ct. App. 2013).

313. See, e.g., Kevin Roose, Seeking Guidance on Dodd-Frank's Diversity Clause, N.Y. TIMES (Nov. 11, 2010), http://www.dealbook.nytimes.com/2010/11/11/seekingguidance-on-dodd-franks-diversity-clause (describing the thinking behind section 342 of the Act, "that putting diversity regulators in the agencies would help to correct racial and gender imbalances at Wall Street firms"); Press Release 2012-163, SEC, SEC Adopts Rule for Disclosing Use of Conflict Minerals (Aug. 22, 2012), available at www.sec.goc/NEWS/PressRelease/Detail/PressRelease/1365171484002.

314. Securities and Exchange Commission, Fiscal Year 2013 Agency Financial Report at 37, available atwww.sec.gov/about/secpar/secafr2013.pdf (noting "budgetary resources" of $\$ 1.4$ billion).

315. See, e.g., View All Bank of America Fees, BANK OF AMERICA, (Sept. 12, 2014), http://www.bankofamerica.com/deposits/bank-account-fees.go (listing, among others, a $\$ 12$ per month maintenance fee for the bank's "Core Checking" account).

316. While private lawsuits have yet to impact Bitcoin regulation, the trend may ultimately reverse. SeeBitcoin Case Survives, NAT'L L. J. (Apr. 28, 2014), http://www.nationallawjournal.com/id=1202652779053/Verdicts-amp-

Settlements?slreturn $=20140819090004$ (describing a local San Francisco court's refusal to dismiss the breach of contract suit by a Bitcoin purchaser against a private seller for $\$ 2,500$ in Bitcoins; the article noted a similar suit against a Bitcoin exchange in a San Francisco court in 2012). 
confidence in the investing populace. More pointedly, the SEC action advocated herein would have legitimacy, provide a federal standard, and please the public.

\section{A. On the SEC's Legitimacy}

Alexander Hamilton wrote that " $[t]$ he propriety of a law, in a constitutional light, must always be determined by the nature of the powers upon which it is founded." ${ }^{\prime 317}$ The federal securities laws were indubitably founded on the premise that American Investors were blindly parting with their monies in hopes of greater returns. ${ }^{318}$ It is undisputed that these initial legislative responses to the horrors of the Great Depression sought foremost to bring markets and products into the light. ${ }^{319}$ In turn, hundreds of federal cases attest to the SEC's authority to look beyond traditional "stocks" listed on rooted exchanges when seeking to serve as the Investor's advocate. ${ }^{320}$

It is thus clear that the SEC acts truest to its purpose when it elevates reality over semantics, and, by so doing, renders transparent the most confusing of trendy investment vehicles. Concurrently, even the champions of the free market have been humbled by the recent financial crisis into recognition of the need for regulation of exotic products. ${ }^{321}$

317. ThE Federalist No.33 (Alexander Hamilton).

318. See, e.g., John K. Galbraith, The Great Crash, 1929 6-7 (7th ed. 1997) (describing the notoriously American faith in "quick, effortless enrichment in the stock market").

319. See, e.g., Massimo Calabresi, The Competitor, TrmE, Apr. 14, 2014, at 34, 36 (detailing the ascent of former prosecutor Mary Jo White to the position of SEC Chair:"The SEC was created 80 years ago in the wake of the 1929 stock-market crash to fix a key cause of Wall Street's Depression-era dysfunction: the corporate secrecy that gave financial titans an unfair advantage over average investors."); see also MICHAEL PERINO, THE HELLHOUND OF WALL STREET, 235 (2010) ("People have a remarkable capacity for self-delusion, particularly when those delusions are congruent with their own financial interest."). Professor Perino details the influence of the famed "[Ferdinand] Pecora Hearings" upon immediately ensuing Congressional reform.Id.

320. See supra notes 292-301 and accompanying text.

321. See, e.g., Interview with Alan Greenspan, Former Chair of the United States Federal Reserve, 10 Questions, TIME,Nov. 4, 2013, at 72 ("I was wrong. You have to regulate the system. My concern about regulation is that it's more vindictive than curative.'); Joel Cohen, An Interview with Judge Richard A. Posner, A.B.A. J., 58 (July 2014) ("I've become much more concerned with . . . consumer protection ... less trustful of purely economic analysis-the last partly because of the crash of 2008 and the ensuing economic downturn. That shook some of my faith in economic analysis."). 


\section{B. On the Practical Need for Uniformity}

Perhaps more noteworthy, in the interest of legal consistency, the growing suspicion and intolerance of Bitcoin by the states needs to be harmonized. Many regulators have-quite justifiably-refused to dignify Bitcoin, no doubt mindful of the old adage that once sharing a canoe with a bear, "it is hard to get him out without obtaining his agreement or getting wet." ${ }^{\text {322 }}$ But a growing number at the local level have taken aim. As varied regulators attempt to limit the destructive potential of a new, nearly incomprehensible investment, ${ }^{323}$ the SEC needs to remind all regulators that the federal watchdog is again federalizing the standards by which investors are shielded, a laudable goal that the agency has readily embraced throughout its storied history (and troubled recent past). ${ }^{324}$

It bears noting that the remedy proposed herein is truly a measured response. China has already banned the use of Bitcoin by banks and merchants; ${ }^{325}$ SEC registration would seek foremost to ensure informed use. Moreover, slimming the investment potential of Bitcoin (as well as the field of exchanges) would surely increase its stability. In a historical sense, placing Bitcoin conversion arrangements more squarely on the Commission radar screen would serve as the alternative currency's greatest victory: Bitcoin has arrived, and is part of the system. ${ }^{326}$ To be part of that system, and, in the interest of protecting American Investors, the product now needs to be rationally confined and honestly, publicly and fully described, just like countless nouveau financial

322. VIRAL V. ACharya, GuaranteEd to Fail/FanNIE MAE. Freddie MaC AND THE DEBACLE OF MORTGAGE FINANCE 61 (2011) (quoting a 1996 Congressional Budget Office report on the two foundering government-sponsored enterprises).

323. See, e.g., Dustin Volz, Ohio Won't Let You Buy Beer With Bitcoin, NAT'L L. J. (Apr. 28, 2014), http://www.nationaljournal.com/tech/ohio-won-t-let-you-buy-beer-withbitcoin-20140428; Sarah Todd, Texas Issues Guidelines on Virtual Currency, AM. BANKER (Apr. 3, 2014, 2:36 PM), http://www.americanbanker.com/issues/179_65/texas-issuesguidelines-on-virtual-currency-1066677-1.html (describing the Texas Banking Commissioner's ruling that ATM providers of Bitcoin might be subject to Texas licensing requirements).

324. See, e.g., Adam Zagorin \& Michael Weisskopf, Inside the Breakdown at the $S E C$, TIME, Feb. 9, 2009, at 34 (detailing "less than aggressive" regulatory efforts by the agency during the stewardship of Republican Chair Christopher Cox).

325. Bitcoin in China: A Dream Dispelled, ECONOMIST (Apr. 12, 2014), http://www.economist.com/news/finance-and-economics/21600736-chinese-regulators-

make-life-hard-crypto-currencies-dream-dispelled (revealing China's dual expulsion of the virtual currency from commerce, both as a virtual currency and as barter for "middlemen between business and credit-card networks").

326. Brustein, supra note 282 (it has been noted that "launching an exchange that would function like the New York Stock Exchange" would serve to legitimize Bitcoin). 
arrangements that preceded it.

\section{On the Public's Perception of the Crusade}

Main Street and Wall Street have both come to fear Bitcoin, ${ }^{327}$ the cyber-currency at once so esoteric and so often linked to drug deals and irretrievable wealth. While the most flagrant examples thereof provide headlines for aggressive prosecutors, the commonplace opportunities for investor fraud grow daily and exponentially. The free market has incentivized Bitcoin but done little to provide rational boundaries therefore. And some regulators remain unconvinced that Bitcoin is simply a currency. ${ }^{328}$

But regulators, even if temporarily as bewildered by cryptocurrency as the public, need not be impotent. Putting aside the possibility of Bitcoin serving tantamount to American dollars (as the IRS has), it readily fits the definition of security when purchased solely by the passive, uninformed consumer for its growth potential. Concurrently, those websites enabling Bitcoin's conversion to profits manifested in traditional currencies often meet the threshold test for investment contracts. These determinations provide a ready entrance for the Securities and Exchange Commission, the statutory agency that has protected the sheep from the financial wolves better than any other watchdog for the past eight decades. And, in 2014, an active SEC is truly a popular notion in the United States. ${ }^{329}$

A final note: in July, the New York State Department of Financial Services announced a proposed regulation that would require possession of a "BitLicense" by all entities converting Bitcoins. ${ }^{330}$ The measure is

327. Compare Brian Brus, Bitcoin only worth what people think it is worth, J. REC. (Oklahoma City) (Mar. 20, 2014), withWhy Financial Services Firms Should Prepare for Bitcoin, supra note 90.

328. See Diekmann, supra note 2 ("That led one state regulator I spoke with to conclude that for now Bitcoin isn't a currency but an (anonymous) payment stream."); Todd, supra note 323 (quoting Banking Commissioner Charles Cooper: "At this point a cryptocurrency like Bitcoin is best viewed like a speculative investment, not as money.").

329. See, e.g., Commissioner Luis A. Aquilar, Speech to North American Securities Administrators Association: Outmanned and Outgunned: Fighting on Behalf of Investors Despite Efforts to Weaken Investor Protections (Apr. 16, 2013), available at www.sec.gov/News/Speech/Detail/Speech/1365171515400 (noting with authority that " $84 \%$ of Americans want the federal government to play an active role in protecting investors.").

330. Evan Weinberger, NY Regulator Proposes 1st-Ever Bitcoin License, LAW360(July 17, 2014, 11:13 AM), http:/www.law360.com/articles/558444/ny-regulatorproposes-1st-ever-bitcoin-license. 
intended to both promote "consumer protections" 331 and thwart cyberattacks. ${ }^{332}$ The SEC thus runs the risk of, once again, being beaten to the punch by a state regulator, ${ }^{333}$ a usurping of authority many had hoped was rendered unlikely by the federalization of the securities laws over eighty years ago. ${ }^{334}$ The Commission needs to act now where so many have remained reticent. ${ }^{335}$ Regulatory activism is required for the new threat of Bitcoin, an investment that simultaneously threatens Investors both young ${ }^{336}$ and elderly alike. ${ }^{337}$ Such regulatory activism has been a hallmark of the American financial system since it rose from the embers of the Great Depression. ${ }^{338}$ Such flexible application of the securities laws has been consistently rewarded by federal courts, and would be greatly appreciated by the American populace, who seem to be once again in need of a champion on a White Horse.

331. William Jackson, NY Seeks Bitcoin Exchange Regulations, INFO. WK. (July 22, 2014, 11:25 AM), http:/www.informationweek.com/government/cybersecurity/ny-seeksbitcoin-exchange-regulations/d/d-id/1297469 (reporting that New York's proposed regulation would mandate background checks on Bitcoin dealers to ensure business that would be conducted "honestly, fairly, equitably, carefully, and efficiently.").

332. Id.

333. In 2003, the State of Oklahoma became the first regulator to charge Bernard Ebbers of WorldCom disrepute, prompting a mild protest by the SEC. SeeMCI Hit with Criminal Charges/Oklahoma Attorney General Charges Ebbers, Sullivan, Others with 15 Counts of Violating State Securities Laws, CNN ONLINE (Aug. 27, 2003, 4:53 PM), http://money.cnn.com/2003/08/27/technology/mci_charges ("The SEC said in a statement that it was 'disappointed' it was not contacted by the Oklahoma Attorney General about the criminal charges filed Wednesday.").

334. See Charles Geisst, Wall Street: A History 229 (1997) ("But even when combined with the state... [blue-sky laws, stock exchange listing rules] were not able to prevent the crash and the hundreds of corporate bankruptcies that followed.").

335. See GAO REPORT, EMERGING REGULATORY, LAW ENFORCEMENT, AND CONSUMER PRotection CHALlenges 37 (2014) (noting, in its review of the efforts of a dozen federal agencies, that "[a]lthough there are numerous interagency collaborative efforts that have addressed virtual currency issues ..., interagency working groups have not focused on consumer protection issues").

336. Id. at 22 ("Additionally, an SEC official told us that virtual-currency-based securities may be attracting individuals who are younger and less experienced than typical investors.").

337. Commissioner Luis A. Aquilar, supra note 329 (referencing an SEC guide for senior investors, who are vulnerable to Bitcoin Ponzi schemes).

338. David Heymsfeld, Fear Itself: The New Deal and the Origins of Our Time, Wash. Law., 42 (June 2014) ("In the United States, the New Deal never abandoned the concept that the economy should be regulated under laws passed by Congress .... The later New Deal returned to the concept of a competitive economy, constrained by some regulation designed to protect consumers and workers."). 